\title{
Organic carbon production, mineralisation and preservation on the Peruvian margin
}

\author{
A. W. Dale ${ }^{1}$, S. Sommer ${ }^{1}$, U. Lomnitz ${ }^{1}$, I. Montes ${ }^{2}$, T. Treude ${ }^{1,3}$, V. Liebetrau ${ }^{1}$, J. Gier ${ }^{1}$, C. Hensen ${ }^{1}$, M. Dengler ${ }^{1}$, \\ K. Stolpovsky ${ }^{1}$, L. D. Bryant ${ }^{1}$, and K. Wallmann ${ }^{1}$ \\ ${ }^{1}$ GEOMAR Helmholtz Centre for Ocean Research Kiel, Kiel, Germany \\ ${ }^{2}$ Instituto Geofísico del Perú (IGP), Lima, Peru \\ ${ }^{3}$ Present address: University of California, Los Angeles (UCLA), USA
}

Correspondence to: A. W. Dale (adale@geomar.de)

Received: 15 August 2014 - Published in Biogeosciences Discuss.: 9 September 2014

Revised: 18 January 2015 - Accepted: 6 February 2015 - Published: 11 March 2015

\begin{abstract}
Carbon cycling in Peruvian margin sediments (11 and $12^{\circ} \mathrm{S}$ ) was examined at 16 stations, from $74 \mathrm{~m}$ water depth on the middle shelf down to $1024 \mathrm{~m}$, using a combination of in situ flux measurements, sedimentary geochemistry and modelling. Bottom water oxygen was below detection limit down to ca. $400 \mathrm{~m}$ and increased to $53 \mu \mathrm{M}$ at the deepest station. Sediment accumulation rates decreased sharply seaward of the middle shelf and subsequently increased at the deep stations. The organic carbon burial efficiency (CBE) was unusually low on the middle shelf $(<20 \%)$ when compared to an existing global database, for reasons which may be linked to episodic ventilation of the bottom waters by oceanographic anomalies. Deposition of reworked, degraded material originating from sites higher up on the slope is proposed to explain unusually high sedimentation rates and $\mathrm{CBE}$ $(>60 \%)$ at the deep oxygenated sites. In line with other studies, CBE was elevated under oxygen-deficient waters in the mid-water oxygen minimum zone. Organic carbon rain rates calculated from the benthic fluxes alluded to efficient mineralisation of organic matter in the water column compared to other oxygen-deficient environments. The observations at the Peruvian margin suggest that a lack of oxygen does not greatly affect the degradation of organic matter in the water column but promotes the preservation of organic matter in sediments.
\end{abstract}

\section{Introduction}

The Peruvian upwelling forms part of the boundary current system of the Eastern Tropical South Pacific and is one of the most biologically productive regions in the world (Pennington et al., 2006). Respiration of organic matter in subsurface waters leads to the development of an extensive and perennial oxygen minimum zone (Walsh, 1981; Quiñones et al., 2010). Bottom water dissolved oxygen $\left(\mathrm{O}_{2}\right)$ concentrations have been measured to be below the analytical detection limit from the shelf down to $400 \mathrm{~m}$ (Bohlen et al., 2011). Sediments within this depth interval display organic carbon contents in excess of $15 \%$ (Reimers and Suess, 1983a; Suess et al., 1987; Arthur et al., 1998); much higher than the average continental margin of $<2 \%$ (Seiter et al., 2004). Oxygendeficient margins like Peru have thus been proposed to be sites of enhanced carbon preservation and petroleum-source rock formation (Demaison and Moore, 1980).

An understanding of the factors that enhance carbon preservation and burial in marine sediments is critical to interpret the sedimentary record and constrain global carbon sources and sinks over geological timescales (Berner, 2004; Wallmann and Aloisi, 2012). Pioneering workers argued that carbon preservation is strongly driven either by the absence of $\mathrm{O}_{2}$ in the bottom water (Demaison and Moore, 1980) or by higher primary production (Pedersen and Calvert, 1990). Since then, much work on the biogeochemical characteristics of sediments has been undertaken to better disentangle these factors (Hedges and Keil, 1995; Arthur et al., 1998; Hedges et al., 1999; Keil and Cowie, 1999; Vanderwiele et al., 2009; 
Zonneveld et al., 2010; and many others). These studies do broadly indicate that organic matter under oxic bottom waters is in a more advanced state of degradation compared to oxygen-deficient waters. Investigations in the water column have also shown that respiration of organic carbon is significantly reduced in oxygen-deficient waters, leading to elevated carbon fluxes to the sediments (Martin et al., 1987; Devol and Hartnett, 2001; Van Mooy et al., 2002).

Rates of carbon burial and mineralisation on the Peruvian margin have been studied as part of the Collaborative Research Center 754 (Sonderforschungsbereich, SFB 754, www.sfb754.de/en) "Climate-Biogeochemistry Interactions in the Tropical Ocean" (first phase 2008-2011 and second phase 2012-2015). The overall aim of the SFB 754 is to understand the physical and biogeochemical processes that lead to the development and existence of oxygen-deficient regions in the tropical oceans. In this paper, in situ benthic fluxes and sedimentary geochemical data collected during two campaigns to the Peruvian margin at 11 and $12^{\circ} \mathrm{S}$ are used to summarise our current understanding of carbon cycling in this setting. We address the following questions:

1. What is the rate of organic carbon mineralisation and burial in the sediments down through the oxygen minimum zone (OMZ)? Do these data point toward diminished rates of organic carbon mineralisation in the water column?

2. Which factors determine the carbon burial efficiency at Peru and is there any marked difference for stations underlying oxic and anoxic bottom waters?

\section{Study area}

Equatorward winds engender upwelling of nutrient-rich equatorial subsurface water along the Peruvian coast (Fiedler and Talley, 2006). Upwelling is most intense between 5 and $15^{\circ} \mathrm{S}$ where the shelf narrows (Quiñones et al., 2010). The sampling transects in this study at 11 and $12^{\circ} \mathrm{S}$ are located within the same upwelling cell (Suess et al., 1987). The highest rates of primary productivity $\left(1.8-3.6 \mathrm{~g} \mathrm{C} \mathrm{m}^{-2} \mathrm{~d}^{-1}\right)$ are 6 months out of phase with upwelling intensity due to the deepening of the mixed layer during the upwelling period (Walsh, 1981; Echevin et al., 2008; Quiñones et al. 2010). Austral winter and spring is the main upwelling period, with interannual variability imposed by the El NiñoSouthern Oscillation (ENSO) (Morales et al., 1999). The lower vertical limit of the OMZ is around $700 \mathrm{~m}$ water depth off Peru $\left(\mathrm{O}_{2}<20 \mu \mathrm{mol} \mathrm{kg}{ }^{-1}\right.$; Fuenzalida et al. 2009). The mean depth of the upper boundary of the OMZ on the shelf at 11 and $12^{\circ} \mathrm{S}$ is around $50 \mathrm{~m}$ (Gutiérrez et al., 2008), but deepens to ca. $200 \mathrm{~m}$ or more during ENSO years (e.g. Levin et al., 2002). At these times, dissolved $\mathrm{O}_{2}$ on the shelf can vary between 0 and $100 \mu \mathrm{M}$ within a matter of days to weeks as opposed to several months during weaker ENSO events (Gutiérrez et al., 2008; Noffke et al., 2012).

Sediments at 11 and $12^{\circ} \mathrm{S}$ are generally diatomaceous, rapidly accumulating muds (Suess et al., 1987, and many others). Grain size analysis shows that clay/silt fractions are highest on the shelf and in mid-waters ( $>80 \%$ ), whereas the sand content is highest (40\%) in deeper waters (Mosch et al., 2012). The sediments can thus be described as sandy mud to slightly sandy mud (Flemming, 2000). The distribution of sediment on the margin is influenced by resuspension, winnowing and lateral particle transport due to bottom currents and breaking of internal waves on the slope (Arthur et al., 1998; Levin et al., 2002; Mosch et al., 2012). Surface particulate organic carbon (POC) content is high in mid-waters (15 to $20 \%$ ) with lower values (5 to $10 \%$ ) on the shelf and in deep waters (Böning et al., 2004). $\delta^{13} \mathrm{C}$ analysis and other geochemical indicators confirm that the organic matter at this latitude is almost entirely of marine origin (Arthur et al., 1998; Reimers and Suess, 1983b; Levin et al., 2002; Gutiérrez et al., 2009).

The sediments down to around $400 \mathrm{~m}$ are notably cohesive, ranging from dark olive green to black in colour with no surface-oxidised layer (Bohlen et al., 2011; Mosch et al., 2012). The surface is colonised by dense, centimetre-thick mats of gelatinous sheaths containing microbial filaments of the large sulfur oxidising bacteria Thioploca spp. (Henrichs and Farrington, 1984; Arntz et al., 1991). These bacteria glide vertically through the sediments to access sulfide, which they oxidise using nitrate stored within intracellular vacuoles (Jørgensen and Gallardo, 2006). The bacterial density varies with time on the shelf, depending on the bottom water redox conditions (Gutiérrez et al., 2008). Spionid polychaetes (ca. $2 \mathrm{~cm}$ length) have been observed in association with the mats (Mosch et al., 2012). The biomass of macrofauna generally tends to be highest in the OMZ but with low species richness, dominated by polychaetes and oligochaetes (Levin et al., 2002). At the lower boundary of the OMZ, high abundances of epibenthic megafauna such as ophiuroids as well as echinoderms, pennatulaceans, Porifera, crustaceans, gastropods and echinoderms have been observed (Levin et al., 2002; Mosch et al., 2012). Sediments here are olive green throughout with a thin upper oxidised layer light green/yellow in colour (Bohlen et al., 2011; Mosch et al., 2012).

For the purposes of this study, we divide the Peruvian margin into three zones broadly reflecting bottom water $\mathrm{O}_{2}$ distributions and sedimentary POC content: (i) the middle and outer shelf ( $<$ ca. $200 \mathrm{~m}$, POC 5 to $10 \%, \mathrm{O}_{2}<$ detection limit $(\mathrm{dl}, 5 \mu \mathrm{M})$ at time of sampling) where non-steady conditions are occasionally driven by periodic intrusion of oxygenated bottom waters; (ii) the OMZ (ca. 200 to $450 \mathrm{~m}$, POC 10 to $20 \%, \mathrm{O}_{2}$ predominantly $<\mathrm{dl}$ ); and (iii) the deep stations below the OMZ with oxygenated bottom water $(\mathrm{POC} \leq$ ca. $5 \%$ and $\mathrm{O}_{2}>\mathrm{dl}$ ). 

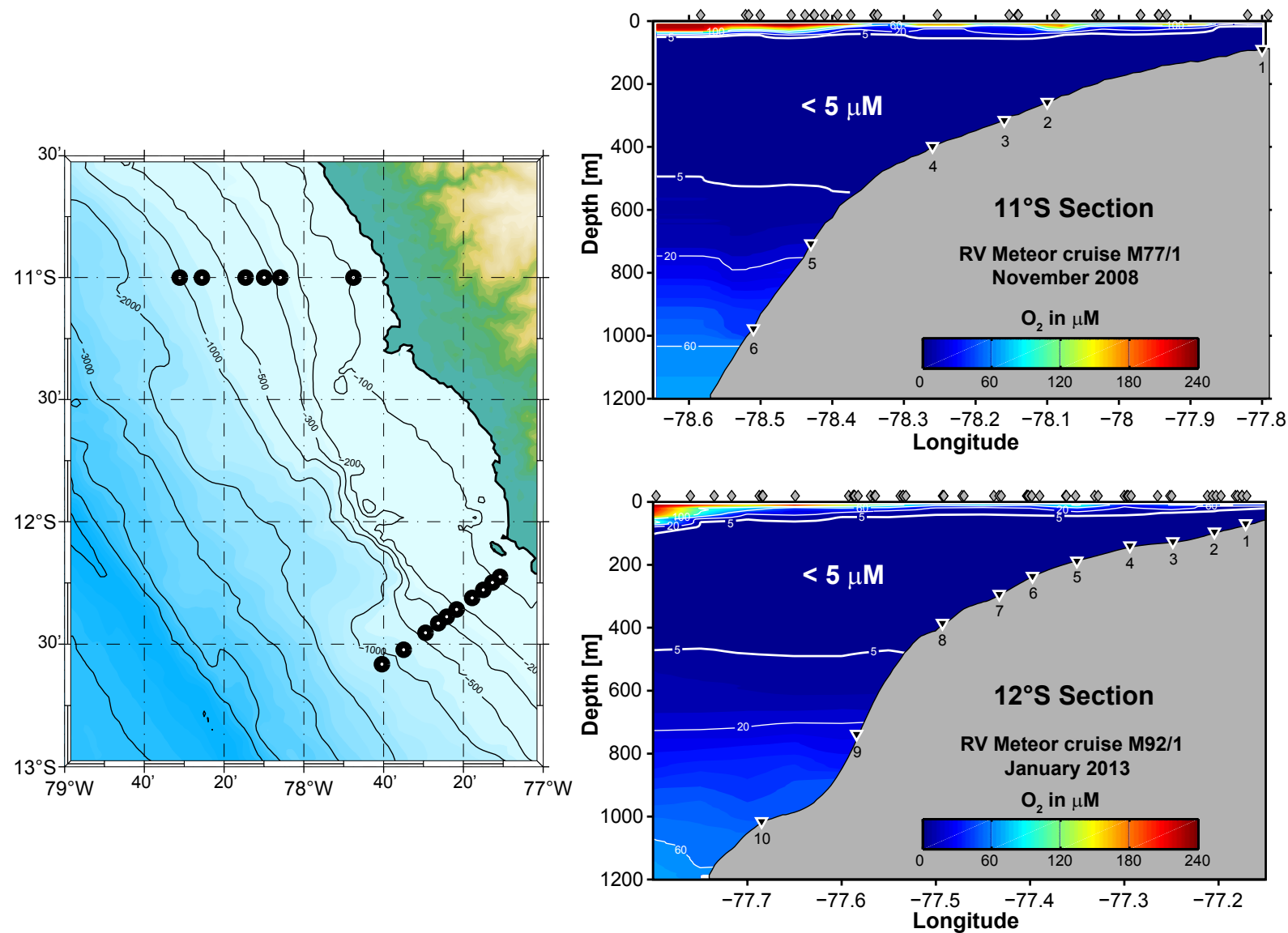

Figure 1. Slope bathymetry (contours in $\mathrm{m}$ ) and benthic sampling stations on the Peruvian margin at 11 and $12^{\circ} \mathrm{S}$ (left). The two panels on the right show cross-sections of dissolved oxygen concentrations $(\mu \mathrm{M})$ measured using the CTD sensor calibrated against Winkler titrations (detection limit $5 \mu \mathrm{M}$ ). The station locations are indicated by the black triangles and the CTD stations used to make the plots are indicated by the grey diamonds.

\section{Material and methods}

\subsection{Flux measurements and sediment sampling}

We present data from six stations along $11^{\circ} \mathrm{S}$ sampled during expedition M77 (cruise legs 1 and 2) in November/December 2008 and ten stations along $12^{\circ} \mathrm{S}$ during expedition M92 (leg 3) in January 2013 (Fig. 1). Both campaigns took place during austral summer, i.e. the low upwelling season, and under neutral or negative ENSO conditions (http://www.cpc. ncep.noaa.gov). With the exception of the particulate phases, the geochemical data and benthic modelling results from the $11^{\circ} \mathrm{S}$ transect have been published previously (Bohlen et al., 2011; Scholz et al., 2011; Mosch et al., 2012; Noffke et al., 2012). Data from $12^{\circ} \mathrm{S}$ are new to this study.

In situ fluxes were measured using data collected from Biogeochemical Observatories, BIGO (Sommer et al., 2008; Dale et al., 2014). BIGO landers contained two circular flux chambers (internal diameter $28.8 \mathrm{~cm}$, area $651.4 \mathrm{~cm}^{2}$ ). One lander at $11^{\circ} \mathrm{S}, \mathrm{BIGO}-\mathrm{T}$, contained only one benthic chamber. Each chamber was equipped with an optode to moni- tor dissolved $\mathrm{O}_{2}$ concentrations. A TV-guided launching system allowed smooth placement of the observatories on the seafloor. Two hours $\left(11^{\circ} \mathrm{S}\right)$ and $4 \mathrm{~h}\left(12^{\circ} \mathrm{S}\right)$ after the landers were placed on the seafloor, the chamber(s) were slowly driven into the sediment $\left(\sim 30 \mathrm{~cm} \mathrm{~h}^{-1}\right)$. During this initial period, the water inside the flux chamber was periodically replaced with ambient bottom water. After the chamber was driven into the sediment $(\sim 10 \mathrm{~cm})$, the chamber water was again replaced with ambient bottom water to flush out solutes that might have been released from the sediment during chamber insertion. The water volume enclosed by the benthic chamber ranged from 7.8 to $18.5 \mathrm{~L}$ and was mixed using a $5 \mathrm{~cm}$ stirrer bar at $140 \mathrm{rpm}$ located $10-15 \mathrm{~cm}$ above the sediment surface. During the BIGO-T experiments, the chamber water was replaced with ambient bottom water halfway through the deployment period to restore outside conditions and then re-incubated.

Four $\left(11^{\circ} \mathrm{S}\right)$ or eight $\left(12^{\circ} \mathrm{S}\right)$ sequential water samples were removed periodically with glass syringes (volume of each syringe $\sim 47 \mathrm{~mL}$ ) to determine fluxes of solutes across 
the sediment-water interface. For BIGO-T, four water samples were taken before and after replacement of the chamber water. The syringes were connected to the chamber using $1 \mathrm{~m}$ long Vygon tubes with an internal volume of $6.9 \mathrm{~mL}$. Prior to deployment, these tubes were filled with distilled water, and great care was taken to avoid enclosure of air bubbles. Concentrations were corrected for dilution using measured chloride concentrations in the syringes and bottom water. Water samples for gas measurements $\left(12^{\circ} \mathrm{S}\right)$ were taken at four regular time intervals using $80 \mathrm{~cm}$ long glass tubes (internal volume ca. $15 \mathrm{~mL}$ ). An additional syringe water sampler (four or eight sequential samples) was used to extract ambient bottom water samples from $30-40 \mathrm{~cm}$ above the seafloor. The benthic incubations were conducted for time periods ranging from 17.8 to $33 \mathrm{~h}$. Immediately after retrieval of the observatories, the water samples were transferred to the onboard cool room set to the average bottom water temperature on the margin $\left(8^{\circ} \mathrm{C}\right)$ for further processing and sub-sampling. Benthic fluxes were estimated from linear regressions of the concentration-time data and corrected for the volume to surface area ratio of the chamber. The volume was estimated on board using the mean height of water above the sediments in the recovered chambers.

Sediment samples for analysis were taken using multiplecorers (MUC) deployed adjacent to the BIGO sites. Retrieved cores were immediately transferred to the cool room and processed within a few hours. Sub-sampling for redox sensitive constituents was performed under anoxic conditions using an argon-filled glove bag. Sediment samples for porosity analysis were transported to the on shore laboratory in air-tight containers at $8{ }^{\circ} \mathrm{C}$. Samples for porewater extraction were centrifuged at $4500 \mathrm{rpm}$ for $20 \mathrm{~min}$. Prior to analysis, the supernatant was filtered with cellulose acetate Nuclepore $^{\circledR}$ filters $(0.2 \mu \mathrm{m})$ inside the glove bag. The centrifugation tubes with the remaining solid phase of the sediment were stored at $-20^{\circ} \mathrm{C}$ for further analysis on shore. Additional samples for bottom water analysis were taken from the water overlying the sediment cores.

\subsection{Analytical details}

Dissolved oxygen concentrations in the water column were measured using a Seabird SBE43 polarographic membrane oxygen sensor mounted on a SeaBird 911 CTD rosette system. The sensors were calibrated against discrete samples collected from the water column on each CTD cast and analysed on board using Winkler titration with a detection limit of ca. $5 \mu \mathrm{M}$. The optodes inside the benthic chambers were calibrated by vigorously bubbling unfiltered bottom seawater with air or argon for $20 \mathrm{~min}$ and calibrated using Winkler. We broadly define $\mathrm{O}_{2}$ concentrations below the detection limit of the Winkler analysis as anoxic, whilst noting that sub-micromolar levels have been measured in the OMZ using microsensors (Kalvelage et al., 2013).
Ammonium $\left(\mathrm{NH}_{4}^{+}\right)$was measured on board using standard photometric techniques with a Hitachi U2800 photometer (Grasshoff et al., 1999). The detection limit was $1 \mu \mathrm{M}$ and the precision of the analyses was $5 \mu \mathrm{M}$. Total alkalinity (TA) was determined by direct titration of $1 \mathrm{~mL}$ porewater with $0.02 \mathrm{M} \mathrm{HCl}$ using a mixture of methyl red and methylene blue as an indicator and bubbling the titration vessel with argon gas to strip $\mathrm{CO}_{2}$ and hydrogen sulfide. The analysis was calibrated using IAPSO seawater standard, with a precision and detection limit of $0.05 \mathrm{meq}^{-1}$. Ion chromatography (Methrom 761) was used to determine sulfate $\left(\mathrm{SO}_{4}^{2-}\right)$ in the onshore laboratory with a detection limit of $<100 \mu \mathrm{M}$ and precision of $200 \mu \mathrm{M}$. Major cations were determined by ICP-AES with a detection limit and precision as given by Haffert et al. (2013).

The partial pressure of $\mathrm{CO}_{2}\left(p \mathrm{CO}_{2}\right)$ was analysed in the benthic chambers at $12^{\circ} \mathrm{S}$ by passing the sample from the glass tubes (without air contact) through the membrane inlet of a quadrupole mass spectrometer (GAM200 IPI Instruments, Bremen). The samples were analysed sequentially, flushing with distilled water between samples. Standards of 300, 500, 1000 and 5000 ppm $\mathrm{CO}_{2}$ were prepared by sparging filtered seawater from the bottom water from each station using standard bottles of $\mathrm{CO}_{2}$ of known concentration at in situ temperature for $30 \mathrm{~min}$. Calibration was performed before and after analysis of the samples from each site. The relative precision of the measurement was $<3 \%$.

Wet sediment samples for analysis of POC and particulate organic nitrogen (PON) were freeze-dried in the home laboratory and analysed using a Carlo-Erba element analyser (NA 1500). POC content was determined after acidifying the sample with $\mathrm{HCl}(0.25 \mathrm{~N})$ to release the inorganic components as $\mathrm{CO}_{2}$. Weight percent of total carbon was determined using samples without acidification. Inorganic carbon was determined by weight difference between the total and organic carbon. The precision and detection limit of the POC analysis was 0.04 and 0.05 dry weight percent $(\% \mathrm{C})$, respectively. The precision and detection limit of the inorganic carbon analysis was 2 and $0.1 \% \mathrm{C}$, respectively. Porosity was determined from the weight difference of the wet and freezedried sediment. Values were converted to porosity (water volume fraction of total sediment) assuming a dry sediment density of $2 \mathrm{~g} \mathrm{~cm}^{-3}$ (Böning et al., 2004) and seawater density of $1.023 \mathrm{~g} \mathrm{~cm}^{-3}$. The analysis of total aluminium (Al) concentrations in digestion solutions was carried out using an inductively coupled plasma optical emission spectrometer (ICPOES, VARIAN 720-ES) following the procedure described by Scholz et al. (2011).

Additional samples from adjacent MUC liners taken from the same cast were used for the determination of downcore profiles of unsupported (excess) ${ }^{210} \mathrm{~Pb}_{\mathrm{xs}}$ activity by gamma counting. This approach includes the monitoring of the main peaks of anthropogenic deposition of ${ }^{241} \mathrm{Am}$ during the 1950s (test of nuclear weapons) as an independent time marker. Between 5 and $34 \mathrm{~g}$ of freeze-dried and ground 
sediment, each averaging discrete $2 \mathrm{~cm}$ depth intervals, was embedded into a 2-phase epoxy resin (West System Inc.), all in the same counter-specific calibrated disc geometry $(2$ inch diameter). Following Mosch et al. (2012), a low-background coaxial $\mathrm{Ge}(\mathrm{Li})$ planar detector (LARI, University of Göttingen) was used to measure total ${ }^{210} \mathrm{~Pb}$ via its gamma peak at $46.5 \mathrm{keV}$ and ${ }^{226} \mathrm{Ra}$ via the granddaughter ${ }^{214} \mathrm{~Pb}$ at $352 \mathrm{keV}$. Prior to analysis, ${ }^{226} \mathrm{Ra}$ and ${ }^{214} \mathrm{~Pb}$ in the gas-tight embedded sediment were allowed to equilibrate for at least 3 weeks. To determine ${ }^{210} \mathrm{~Pb}_{\mathrm{xs}}$, the measured total ${ }^{210} \mathrm{~Pb}$ activity of each sample was corrected by subtracting its individual ${ }^{226} \mathrm{Ra}$ activity, assuming post-burial closed-system behaviour. Uncertainty of the ${ }^{210} \mathrm{~Pb}_{\mathrm{xs}}$ data was calculated from the individual measurements of ${ }^{210} \mathrm{~Pb}$ and ${ }^{226} \mathrm{Ra}$ activities using standard propagation rules. The relative error of the measurements $(2 \sigma)$ ranged between 8 and $58 \%$.

\subsection{Calculation of dissolved inorganic carbon (DIC) fluxes}

DIC concentrations in the benthic chambers at $12^{\circ} \mathrm{S}$ were calculated from the concentrations of TA and $p \mathrm{CO}_{2}$ using the equations and equilibrium coefficients given by Zeebe and Wolf-Gladrow (2001). Since four samples for $p \mathrm{CO}_{2}$ were taken using the glass tubes versus eight samples for TA analysis in the syringes, each successive pair of TA data were averaged for calculating DIC (see Supplement). A constant salinity (35 psu), total boron concentration $(0.418 \mathrm{mM})$ and seawater density $\left(1.025 \mathrm{~kg} \mathrm{~L}^{-1}\right)$ were assumed. For the shelf stations where sulfide was released from the sediment (Sommer et al., unpub. data), corrections were made for the contribution of $\mathrm{HS}^{-}$to TA using the relevant equilibrium constants (Zeebe and Wolf-Gladrow, 2001). DIC fluxes were calculated from the concentrations as described above.

\subsection{Determination of sediment accumulation rates}

Particle-bound ${ }^{210} \mathrm{~Pb}_{\mathrm{xs}}$ is subject to mixing in the upper sediment layers by the movement of benthic fauna. The distribution of ${ }^{210} \mathrm{~Pb}_{\mathrm{xs}}$ can thus be used to determine bioturbation coefficients as well as sedimentation rates using a reactiontransport model. We simulated the activity of ${ }^{210} \mathrm{~Pb}_{\mathrm{xs}}$ in $\mathrm{Bq} \mathrm{g}^{-1}$ using a steady-state numerical model that includes terms for sediment burial, mixing (bioturbation), compaction and radioactive decay:

$$
\begin{aligned}
& (1-\varphi(x)) \times \rho \times \frac{\partial^{210} \mathrm{~Pb}_{\mathrm{xs}}(x)}{\partial t}= \\
& \frac{\partial\left((1-\varphi(x)) \times \rho \times D_{\mathrm{B}}(x) \times \frac{\partial^{210} \mathrm{~Pb}_{\mathrm{xs}}(x)}{\partial x}\right)}{\partial x} \\
& -\frac{\partial\left((1-\varphi(x)) \times \rho \times v_{\mathrm{s}}(x) \times{ }^{210} \mathrm{~Pb}_{\mathrm{xs}}(x)\right)}{\partial x} \\
& +(1-\varphi(x)) \times \rho \times \lambda^{210} \times \mathrm{Pb}_{\mathrm{xs}}(x) .
\end{aligned}
$$

In this equation, $t(\mathrm{yr})$ is time, $x(\mathrm{~cm})$ is depth below the sediment-water interface, $\varphi(x)$ (dimensionless) is porosity, $v_{\mathrm{s}}(x)\left(\mathrm{cm} \mathrm{yr}^{-1}\right)$ is the burial velocity for solids, $D_{\mathrm{B}}(x)$ $\left(\mathrm{cm}^{2} \mathrm{yr}^{-1}\right)$ is the bioturbation coefficient, $\lambda\left(0.03114 \mathrm{yr}^{-1}\right)$ is the decay constant for ${ }^{210} \mathrm{~Pb}_{\mathrm{xs}}$ and $\rho\left(2.0 \mathrm{~g} \mathrm{~cm}^{-3}\right)$ is the bulk density of solid particles.

Porosity was described using an exponential function assuming steady-state compaction:

$\varphi(x)=\varphi(L)+(\varphi(0)-\varphi(L)) \times \exp \left(-\frac{x}{z_{\text {por }}}\right)$,

where $\varphi(0)$ is the porosity at the sediment-water interface, $\varphi(L)$ is the porosity of compacted sediments and $z_{\text {por }}(\mathrm{cm})$ is the attenuation coefficient. These parameters were determined from the measured data at each station (Table S2 in Supplement).

Sediment compaction was considered by allowing the sediment burial velocity to decrease with sediment depth:

$v_{\mathrm{s}}(x)=\frac{\omega_{\mathrm{acc}} \times(1-\varphi(L))}{1-\varphi(x)}$,

where $\omega_{\text {acc }}$ corresponds to the sediment accumulation rate of compacted sediments.

The decrease in bioturbation intensity with depth was described with a Gaussian-type function (Christensen, 1982):

$D_{\mathrm{B}}(x)=D_{\mathrm{B}}(0) \times \exp \left(-\frac{x^{2}}{2 \times x_{\mathrm{S}}^{2}}\right)$,

where $D_{\mathrm{B}}(0)\left(\mathrm{cm}^{2} \mathrm{yr}^{-1}\right)$ is the bioturbation coefficient at the sediment-water interface and $x_{\mathrm{s}}(\mathrm{cm})$ is the bioturbation halving depth.

The flux continuity at the sediment surface serves as the upper boundary condition:

$$
\begin{aligned}
& F(0)=(1-\varphi(0)) \times \rho \times \\
& \left(v_{\mathrm{s}}(0) \times{ }^{210} \mathrm{~Pb}_{\mathrm{xs}}(0)-D_{\mathrm{B}}(0) \times\left.\frac{\partial^{210} \mathrm{~Pb}_{\mathrm{xs}}(x)}{\partial x}\right|_{0}\right),
\end{aligned}
$$

where $F(0)$ is the steady-state flux of ${ }^{210} \mathrm{~Pb}_{\mathrm{xs}}$ to the sediment surface $\left(\mathrm{Bq} \mathrm{cm}^{-2} \mathrm{yr}^{-1}\right)$. The influx of ${ }^{210} \mathrm{~Pb}_{\mathrm{xs}}$ was determined from the measured integrated activity of ${ }^{210} \mathrm{~Pb}_{\mathrm{xs}}$ multiplied by $\lambda$ :

$F(0)=\lambda \times \rho \int_{0}^{\infty}{ }^{210} \mathrm{~Pb}_{\mathrm{xS}}(x) \times(1-\varphi(x)) \mathrm{d} x$.

${ }^{210} \mathrm{~Pb}_{\mathrm{xs}}$ was present down to the bottom of the core at the $74 \mathrm{~m}$ station $\left(12^{\circ} \mathrm{S}\right)$, implying rapid burial rates. Here, $F(0)$ was adjusted until a fit to the data was obtained.

A zero gradient (Neumann) condition was imposed at the lower boundary at $50 \mathrm{~cm}(100 \mathrm{~cm}$ for the shallowest stations at $\left.12^{\circ} \mathrm{S}\right)$. At this depth, all ${ }^{210} \mathrm{~Pb}_{\mathrm{xs}}$ will have decayed 
for the burial rates encountered on the Peruvian margin. The model was initialised using low and constant values for ${ }^{210} \mathrm{~Pb}_{\mathrm{xs}}$ in the sediment column. Solutions were obtained using the numerical solver NDSolve in MATHEMATICA 9 with a mass conservation $>99 \%$.

The adjustable parameters $\left(\omega_{\mathrm{acc}}, D_{\mathrm{B}}(0), x_{\mathrm{s}}\right)$ were constrained by fitting the ${ }^{210} \mathrm{~Pb}_{\mathrm{xs}}$ data. Unsupported ${ }^{210} \mathrm{~Pb}$ measurements were not made at the 101 and $244 \mathrm{~m}$ station $\left(12^{\circ} \mathrm{S}\right)$ and sedimentation rates here were estimated from adjacent stations. Parameters and boundary conditions for simulating ${ }^{210} \mathrm{~Pb}_{\mathrm{xs}}$ at $12^{\circ} \mathrm{S}$ are given in Table $\mathrm{S} 2$ and in Bohlen et al. (2011) for $11^{\circ} \mathrm{S}$. For some cores, the subsampling strategy revealed the detection of the anthropogenic enrichment peak of nuclide ${ }^{241} \mathrm{Am}$ (co-analysed on $60 \mathrm{keV}$ ). This provides an independent time marker in the profiles and potential validation of the radiometric age model deduced from the ${ }^{210} \mathrm{~Pb}_{\mathrm{xs}}$-based sediment accumulation rates.

\subsection{Diagenetic modelling of POC degradation}

A steady-state 1-D numerical reaction-transport model was used to simulate the degradation of POC in surface sediments at all stations. The model developed for $12^{\circ} \mathrm{S}$ is based on that used to quantify benthic $\mathrm{N}$ fluxes at $11^{\circ} \mathrm{S}$ by Bohlen et al. (2011) with modifications to account for benthic denitrification by foraminifera (Glock et al., 2013).

The basic model framework follows Eq. (1). Solutes were transported by molecular diffusion, sediment accumulation (burial) and non-local transport by burrowing organisms (bioirrigation) in oxygenated sediments below the OMZ. Solid transport by burial and bioturbation was parameterised using the results of the ${ }^{210} \mathrm{~Pb}_{\mathrm{xs}}$ model. Model sensitivity analysis based on solute fluxes showed that bioirrigation rates were very low.

The model includes a comprehensive set of redox reactions that are ultimately driven by POC mineralisation. POC was degraded by aerobic respiration, denitrification, iron oxide reduction, sulfate reduction and methanogenesis. Manganese oxide reduction was not considered due to negligible total manganese in the sediment (Scholz et al., 2011). The rate of each carbon degradation pathway was determined using Michaelis-Menten kinetics based on traditional approaches (e.g. Boudreau, 1996). DIC is produced by POC degradation only, that is, carbonate dissolution or precipitation are not included (see Results).

The total rate of POC degradation was constrained using a nitrogen-centric approach based on the relative rates of transport and reactions that produce/consume $\mathrm{NH}_{4}^{+}$. The procedure follows a set of guidelines that is outlined fully in Bohlen et al. (2011). The modelled POC mineralisation rates for $11^{\circ} \mathrm{S}$ were constrained using both porewater concentration data and in situ flux measurements of $\mathrm{NO}_{3}^{-}, \mathrm{NO}_{2}^{-}$ and $\mathrm{NH}_{4}^{+}$. Dissolved $\mathrm{O}_{2}$ flux data were used as an additional constraint at the deeper stations. The POC degradation rates at $12^{\circ} \mathrm{S}$ were further constrained from the measured
DIC fluxes. The model output includes concentration profiles, benthic fluxes and reaction rates, which are assumed to be in steady state. Note, however, that the bottom waters on the middle shelf at $12^{\circ} \mathrm{S}$ were temporarily depleted in $\mathrm{NO}_{3}^{-}$and $\mathrm{NO}_{2}^{-}$at the time of sampling. Although this leads to uncertainties in the rate of nitrate uptake by Thioploca, POC degradation rates remain well-constrained from the DIC fluxes.

The model was solved in the same way as described for ${ }^{210} \mathrm{~Pb}_{\mathrm{xs}}$. The sediment depth ranged from 50 to $100 \mathrm{~cm}$ depending on the station (Boudreau, 1996). Measured solute concentrations and known or estimated particulate fluxes to the seafloor served as upper boundary conditions (Bohlen et al., 2011). At the lower boundary, a Neumann (zero flux) boundary was generally implemented. A steady-state solution was obtained (invariant concentrations with time and sediment depth) with a mass conservation $>99 \%$.

\subsection{Pelagic modelling of primary production}

Primary production was estimated using the high-resolution physical-biogeochemical model (ROMS-BioEBUS) in a configuration developed for the Eastern Tropical Pacific (Montes et al., 2014). It consists of the hydrodynamic model ROMS (Regional Ocean Model System; Shchepetkin and McWilliams, 2003) coupled with the BIOgeochemical model developed for the Eastern Boundary Upwelling Systems (BioEBUS, Gutknecht et al., 2013). BioEBUS describes the pelagic distribution of $\mathrm{O}_{2}$ and the $\mathrm{N}$ cycle under a range of redox conditions with twelve compartments: phytoplankton and zooplankton split into small (flagellates and ciliates, respectively) and large organisms (diatoms and copepods, respectively); detritus; $\mathrm{NO}_{3}^{-} ; \mathrm{NO}_{2}^{-} ; \mathrm{NH}_{4}^{+}$; dissolved organic $\mathrm{N}$; and a parameterisation to determine nitrous oxide $\left(\mathrm{N}_{2} \mathrm{O}\right)$ production (Suntharalingam et al., 2000, 2012).

The model configuration covers the region between $4^{\circ} \mathrm{N}$ and $20^{\circ} \mathrm{S}$ and from $90^{\circ} \mathrm{W}$ to the west coast of South America. The model horizontal resolution is $1 / 9^{\circ}$ (ca. $12 \mathrm{~km}$ ) and has 32 vertical levels that are elongated toward the surface to provide a better representation of shelf processes. The model was forced by heat and freshwater fluxes derived from COADS ocean surface monthly climatology (Da Silva et al., 1994) and by the monthly wind stress climatology computed from QuikSCAT satellite scatterometer data (Liu et al., 1998). The three open boundary conditions (northern, western and southern) for the dynamic variables (temperature, salinity and velocity fields) were extracted from the Simple Ocean Data Assimilation (SODA) reanalysis (Carton and Giese, 2008). Initial and boundary conditions for biogeochemical variables were extracted from the CSIRO Atlas of Regional Seas (CARS 2009; for $\mathrm{NO}_{3}^{-}$and $\mathrm{O}_{2}$ ) and SeaWiFS (O'Reilly et al., 2000; for chlorophyll $a$ ). Other biogeochemical variables were computed following Gutknecht et al. (2013) and Montes et al. (2014). Monthly chlorophyll climatology from SeaWiFS was used to generate phytoplank- 


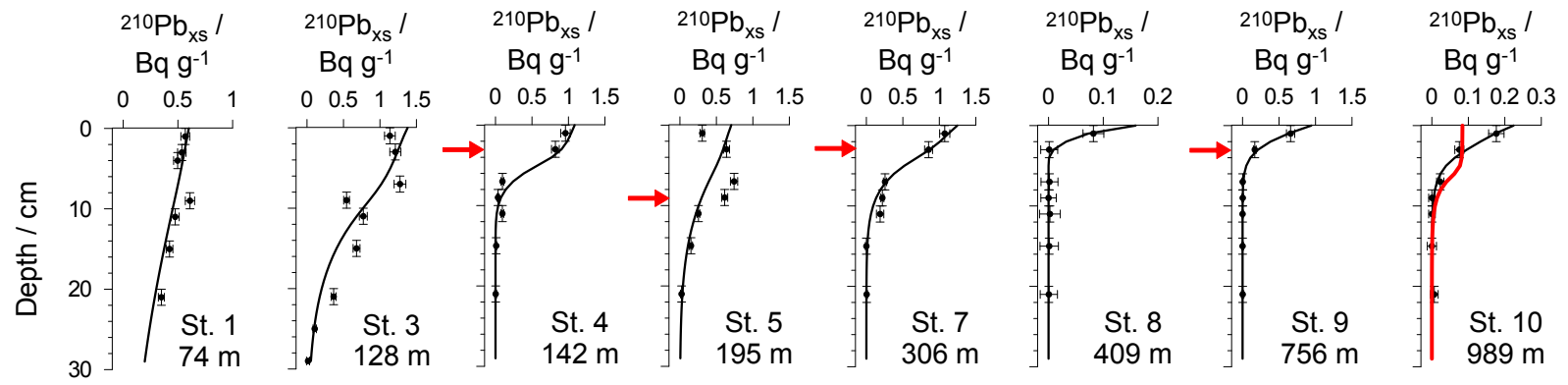

Figure 2. Measured (symbols) and modelled (curves) ${ }^{210} \mathrm{~Pb}_{\mathrm{xs}}$ at $12^{\circ} \mathrm{S}$ (see Bohlen et al. (2011) for ${ }^{210} \mathrm{~Pb}_{\mathrm{xs}}$ at $11^{\circ} \mathrm{S}$ ). Vertical error bars span the depth interval from where the sample was taken, whereas horizontal error bars correspond to the analytical uncertainty. Derived upper boundary fluxes and bioturbation coefficients are listed in Table S2. The red arrows indicate the profile steps reflecting the detection of ${ }^{241} \mathrm{Am}$ and indicating the depth-position of the peak with activities as follows: St. $4=3.7 \pm 1.0 \mathrm{~Bq} \mathrm{~kg}^{-1} ; \mathrm{St} .5=5.8 \pm 0.99 \mathrm{~Bq} \mathrm{~kg}-1$; St. $7=6.6 \pm 0.95 \mathrm{~Bq} \mathrm{~kg}^{-1}$; St. $9=2.2 \pm 0.68 \mathrm{~Bq} \mathrm{~kg}^{-1}$. The accuracy of the peak depth is defined by the sampling resolution. The red curve at St. 10 shows the results of a model simulation using the ${ }^{234}$ Th-derived bioturbation coefficient of $100 \mathrm{~cm}^{2} \mathrm{yr}^{-1}$ (see Appendix A).

ton concentrations, which were then extrapolated vertically from the surface values using the parameterisation of Morel and Berthon (1989). Based on Koné et al. (2005), a crossshore profile following in situ observations was applied to zooplankton, with higher concentrations near the coast.

The simulation period was 18 years: the first 13 years considered the hydrodynamics only, and then the biogeochemical model was coupled for the following 5 years. The coupled model reached a statistical equilibrium after 4 years. The data presented here correspond to the final simulation year. Details of model configuration and validation are described by Montes et al. (2014).

Primary production (PP) was computed as the sum of the production supported by $\mathrm{NO}_{3}^{-}$and $\mathrm{NO}_{2}^{-}$uptake and regenerated production of $\mathrm{NH}_{4}^{+}$uptake by nano- and microphytoplankton (Gutknetch et al., 2013). Rates (in N units) were calculated for the station locations listed in Table 1 by integrating over the euphotic zone. The atomic Redfield $\mathrm{C}: \mathrm{N}$ ratio (106/16, Redfield et al., 1963) was used to convert PP into carbon units.

\section{Results}

\subsection{Sediment appearance}

Bottom sediments at $12^{\circ} \mathrm{S}$ were very similar to those at $11^{\circ} \mathrm{S}$ (see Sect. 2). The sediments down to ca. $300 \mathrm{~m}$ were cohesive, dark-olive anoxic mud (Gutiérrez et al., 2009; Bohlen et al., 2011; Mosch et al., 2012). Porosity was high on the shelf and in the OMZ $(>0.9)$ deceasing to $<0.8$ at the deepest stations (Fig. S1 in Supplement and Table 1). Porewater had a strong sulfidic odour, especially in the deeper layers. Shelf and OMZ sediments were colonised by mats of large filamentous bacteria, presumably Thioploca spp. (Gallardo, 1977; Henrichs and Farrington, 1984). Surface coverage by bacterial mats was $100 \%$ on the shelf and decreased to roughly $40 \%$ by $300 \mathrm{~m}$ where the bacteria formed patches
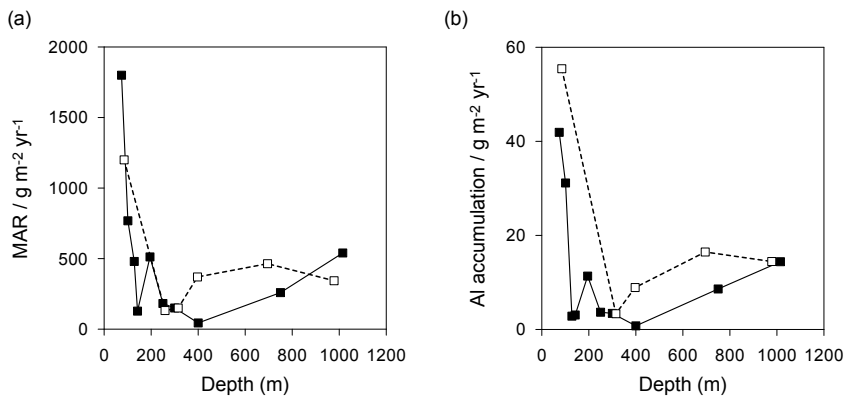

Figure 3. (a) Bulk sediment mass accumulation rates and (b) aluminium accumulation rates at $11^{\circ} \mathrm{S}$ (open symbols) and $12^{\circ} \mathrm{S}$ (closed symbols).

several decimetres in diameter. Mat density was much lower at $11^{\circ} \mathrm{S}$, not exceeding $10 \%$ coverage (Mosch et al., 2012). Thioploca trichomes extended $2 \mathrm{~cm}$ into the overlying water to access bottom water $\mathrm{NO}_{3}^{-}$(cf. Huettel et al., 1996) and were visible down to a depth of ca. $20 \mathrm{~cm}$ at the mat stations. Polychaetes and oligochaetes were also present on the shelf, but not at the deeper stations within the OMZ. Despite anoxic bottom waters, no mats were visible at St. $8(409 \mathrm{~m}$, $12^{\circ} \mathrm{S}$ ). Sediments here consisted of hard grey clay underlying a $2-3 \mathrm{~cm}$ porous surface layer that was interspersed with $\mathrm{cm}$-sized phosphorite nodules. The upper layer contained large numbers of live foraminifera that were visible to the naked eye (J. Cardich et al., unpublished data). Similar foraminiferal "sands" containing phosphorite granules were noted at $11^{\circ} \mathrm{S}$, in particular below the OMZ (Mosch et al., 2012). Phosphorite sands on the Peruvian margin were found in areas of enhanced sediment reworking by bottom currents and the breaking of internal waves on the seafloor (Suess, 1981; Glenn and Arthur, 1988; Mosch et al., 2012). Below the OMZ, macrofauna were more prevalent and included harpacticoids, amphipods, oligochaetes and large polychaetes. 
Table 1. Stations and instruments deployed on the Peruvian margin. Water depths were recorded from the ship's winch. Bottom water temperature and dissolved oxygen are CTD measurements. Surface $\left(0.5 \mathrm{~cm}, 11^{\circ} \mathrm{S} ; 0.25 \mathrm{~cm}, 12^{\circ} \mathrm{S}\right)$ porosity values are also given.

\begin{tabular}{|c|c|c|c|c|c|c|c|c|}
\hline Station & Instrument $^{\mathrm{a}}$ & Date & $\begin{array}{l}\text { Latitude } \\
(\mathrm{S})\end{array}$ & $\begin{array}{r}\text { Longitude } \\
\text { (W) }\end{array}$ & $\begin{array}{r}\text { Depth } \\
(\mathrm{m})\end{array}$ & $\begin{array}{r}\text { Temp. } \\
\left({ }^{\circ} \mathrm{C}\right)\end{array}$ & $\begin{array}{r}\text { Porosity } \\
(-)\end{array}$ & $\begin{array}{l}\mathrm{O}_{2}{ }^{\mathrm{c}} \\
\left({ }^{\circ} \mathrm{C}\right)\end{array}$ \\
\hline & $11^{\circ} \mathrm{S}$ & & & & & & & \\
\hline \multirow[t]{2}{*}{1} & BIGO 5 & 15 Nov 2008 & $11^{\circ} 00.02^{\prime}$ & $77^{\circ} 47.72^{\prime}$ & 85 & 12.7 & & $\mathrm{bdl}$ \\
\hline & MUC 52 & 12 Nov 2008 & $10^{\circ} 59.99^{\prime}$ & $77^{\circ} 47.40^{\prime}$ & 78 & & 0.93 & \\
\hline 2 & BIGO-T6 $6^{\mathrm{d}}$ & 29 Nov 2008 & $10^{\circ} 59.80^{\prime}$ & $78^{\circ} 05.91^{\prime}$ & 259 & 12.2 & 0.95 & bdl \\
\hline \multirow[t]{2}{*}{3} & BIGO 1 & 05 Nov 2008 & $11^{\circ} 00.00^{\prime}$ & $78^{\circ} 09.92^{\prime}$ & 315 & 11.6 & & bdl \\
\hline & MUC 19 & 03 Nov 2008 & $11^{\circ} 00.01^{\prime}$ & $78^{\circ} 09.97^{\prime}$ & 319 & & 0.95 & \\
\hline \multirow[t]{2}{*}{4} & BIGO 3 & 20 Nov 2008 & $11^{\circ} 00.02^{\prime}$ & $78^{\circ} 15.27^{\prime}$ & 397 & 9.6 & & bdl \\
\hline & MUC 33 & 06 Nov 2008 & $11^{\circ} 00.00^{\prime}$ & $78^{\circ} 14.19^{\prime}$ & 376 & & 0.93 & \\
\hline \multirow[t]{2}{*}{5} & BIGO 2 & 05 Nov 2008 & $11^{\circ} 00.01^{\prime}$ & $78^{\circ} 25.55^{\prime}$ & 695 & 6.7 & & 6.2 \\
\hline & MUC 25 & 04 Nov 2008 & $11^{\circ} 00.03^{\prime}$ & $78^{\circ} 25.60^{\prime}$ & 697 & & 0.84 & \\
\hline \multirow[t]{3}{*}{6} & $\mathrm{BIGO} 6^{\mathrm{d}}$ & 29 Nov 2008 & $10^{\circ} 59.82^{\prime}$ & $78^{\circ} 31.05^{\prime}$ & 978 & 4.7 & & 40.3 \\
\hline & MUC 53 & 13 Nov 2008 & $10^{\circ} 59.81^{\prime}$ & $78^{\circ} 31.27^{\prime}$ & 1005 & & 0.78 & \\
\hline & $12^{\circ} \mathrm{S}$ & & & & & & & \\
\hline \multirow[t]{3}{*}{1} & BIGO I-II & 15 Jan 2013 & $12^{\circ} 13.506^{\prime}$ & $77^{\circ} 10.793^{\prime}$ & 74 & 14.0 & & bdl \\
\hline & MUC 13 & 11 Jan 2013 & $12^{\circ} 13.496^{\prime}$ & $77^{\circ} 10.514^{\prime}$ & 71 & & 0.96 & \\
\hline & MUC 39 & 25 Jan 2013 & $12^{\circ} 13.531^{\prime}$ & $77^{\circ} 10.061^{\prime}$ & 72 & & 0.96 & \\
\hline \multirow[t]{2}{*}{2} & BIGO I-V & 27 Jan 2013 & $12^{\circ} 14.898^{\prime}$ & $77^{\circ} 12.705^{\prime}$ & 101 & 13.8 & & bdl \\
\hline & MUC 16 & 12 Jan 2013 & $12^{\circ} 14.897^{\prime}$ & $77^{\circ} 12.707^{\prime}$ & 103 & & 0.97 & \\
\hline \multirow[t]{2}{*}{3} & BIGO II-IV & 20 Jan 2013 & $12^{\circ} 16.689^{\prime}$ & $77^{\circ} 14.995^{\prime}$ & 128 & 13.7 & & bdl \\
\hline & MUC 46 & 27 Jan 2013 & $12^{\circ} 16.697^{\prime}$ & $77^{\circ} 15.001^{\prime}$ & 129 & & 0.98 & \\
\hline \multirow[t]{2}{*}{4} & BIGO I-I & 11 Jan 2013 & $12^{\circ} 18.711^{\prime}$ & $77^{\circ} 17.803^{\prime}$ & 142 & 13.4 & & bdl \\
\hline & MUC 10 & 09 Jan 2013 & $12^{\circ} 18.708^{\prime}$ & $77^{\circ} 17.794^{\prime}$ & 145 & & 0.96 & \\
\hline \multirow[t]{2}{*}{5} & BIGO I-IV & 23 Jan 2013 & $12^{\circ} 21.502^{\prime}$ & $77^{\circ} 21.712^{\prime}$ & 195 & 13.0 & & bdl \\
\hline & MUC 45 & 27 Jan 2013 & $12^{\circ} 21.491^{\prime}$ & $77^{\circ} 21.702^{\prime}$ & 195 & & 0.96 & \\
\hline \multirow[t]{3}{*}{6} & BIGO II-II & 12 Jan 2013 & $12^{\circ} 23.301^{\prime}$ & $77^{\circ} 24.284^{\prime}$ & 244 & 12.0 & & bdl \\
\hline & MUC 5 & 07 Jan 2013 & $12^{\circ} 23.329^{\prime}$ & $77^{\circ} 24.185^{\prime}$ & 253 & & 0.96 & \\
\hline & MUC 34 & 23 Jan 2013 & $12^{\circ} 23.300^{\prime}$ & $77^{\circ} 24.228^{\prime}$ & 244 & & 0.96 & \\
\hline \multirow[t]{3}{*}{7} & BIGO II-I & 08 Jan 2013 & $12^{\circ} 24.905^{\prime}$ & $77^{\circ} 26.295^{\prime}$ & 306 & 12.5 & & bdl \\
\hline & MUC 9 & 08 Jan 2013 & $12^{\circ} 24.894^{\prime}$ & $77^{\circ} 26.301^{\prime}$ & 304 & & 0.95 & \\
\hline & MUC 36 & 24 Jan 2013 & $12^{\circ} 25.590^{\prime}$ & $77^{\circ} 25.200^{\prime}$ & 297 & & 0.95 & \\
\hline \multirow[t]{3}{*}{8} & BIGO II-V & 24 Jan 2013 & $12^{\circ} 27.207^{\prime}$ & $77^{\circ} 29.517^{\prime}$ & 409 & 10.6 & & bdl \\
\hline & MUC 23 & 15 Jan 2013 & $12^{\circ} 27.198^{\prime}$ & $77^{\circ} 29.497^{\prime}$ & 407 & & 0.90 & \\
\hline & MUC 24 & 15 Jan 2013 & $12^{\circ} 27.195^{\prime}$ & $77^{\circ} 29.483^{\prime}$ & 407 & & - & \\
\hline \multirow[t]{2}{*}{9} & BIGO II-III & 16 Jan 2013 & $12^{\circ} 31.366^{\prime}$ & $77^{\circ} 34.997^{\prime}$ & 756 & 5.5 & & 19 \\
\hline & MUC 17 & 13 Jan 2013 & $12^{\circ} 31.374^{\prime}$ & $77^{\circ} 35.183^{\prime}$ & 770 & & 0.84 & \\
\hline \multirow[t]{2}{*}{10} & BIGO I-III & 19 Jan 2013 & $12^{\circ} 34.911^{\prime}$ & $77^{\circ} 40.365^{\prime}$ & 989 & 4.4 & & 53 \\
\hline & MUC 28 & 19 Jan 2013 & $12^{\circ} 35.377^{\prime}$ & $77^{\circ} 40.975^{\prime}$ & 1024 & & 0.74 & \\
\hline
\end{tabular}

\footnotetext{
${ }^{\mathrm{a}}$ The first Roman numeral of the BIGO code for $12^{\circ} \mathrm{S}$ denotes the lander used and the second to the deployment number of that lander. For $11^{\circ} \mathrm{S}$, the Arabic number refers to the deployment number. The lander at St. 2 is denoted BIGO-T (see text). ${ }^{b}$ Full porosity profiles are given in the Supplement. ${ }^{\mathrm{c}}$ bdl $=$ below detection limit $(5 \mu \mathrm{M}) .{ }^{\mathrm{d}}$ These deployments occurred during leg 2 of cruise M77. All others from $11^{\circ} \mathrm{S}$ took place during leg 1.
}

\subsection{Sediment mixing and accumulation rates}

At most stations, ${ }^{210} \mathrm{~Pb}_{\mathrm{xs}}$ distributions decreased quasiexponentially and showed little evidence of intense, deep mixing by bioturbation (Fig. 2 and Bohlen et al., 2011); a feature that is supported by the lack of large bioturbating organisms in and below the OMZ. The highest bioturbation co- efficient determined by the model was $4 \mathrm{~cm}^{2} \mathrm{yr}^{-1}$ for St. 3 at $12^{\circ} \mathrm{S}$ (Table S2).

Mass accumulation rates (MAR) derived from ${ }^{210} \mathrm{~Pb}_{\mathrm{xs}}$ modelling (Fig. 3a) were similar to values reported previously (Reimers and Suess, 1983c). Rates were extremely high at the shallowest stations (1200 and $1800 \mathrm{~g} \mathrm{~m}^{-2} \mathrm{yr}^{-1}$ at 11 and $12^{\circ} \mathrm{S}$, respectively). These are a factor of $2-3$ times higher than measured elsewhere on the transects and 


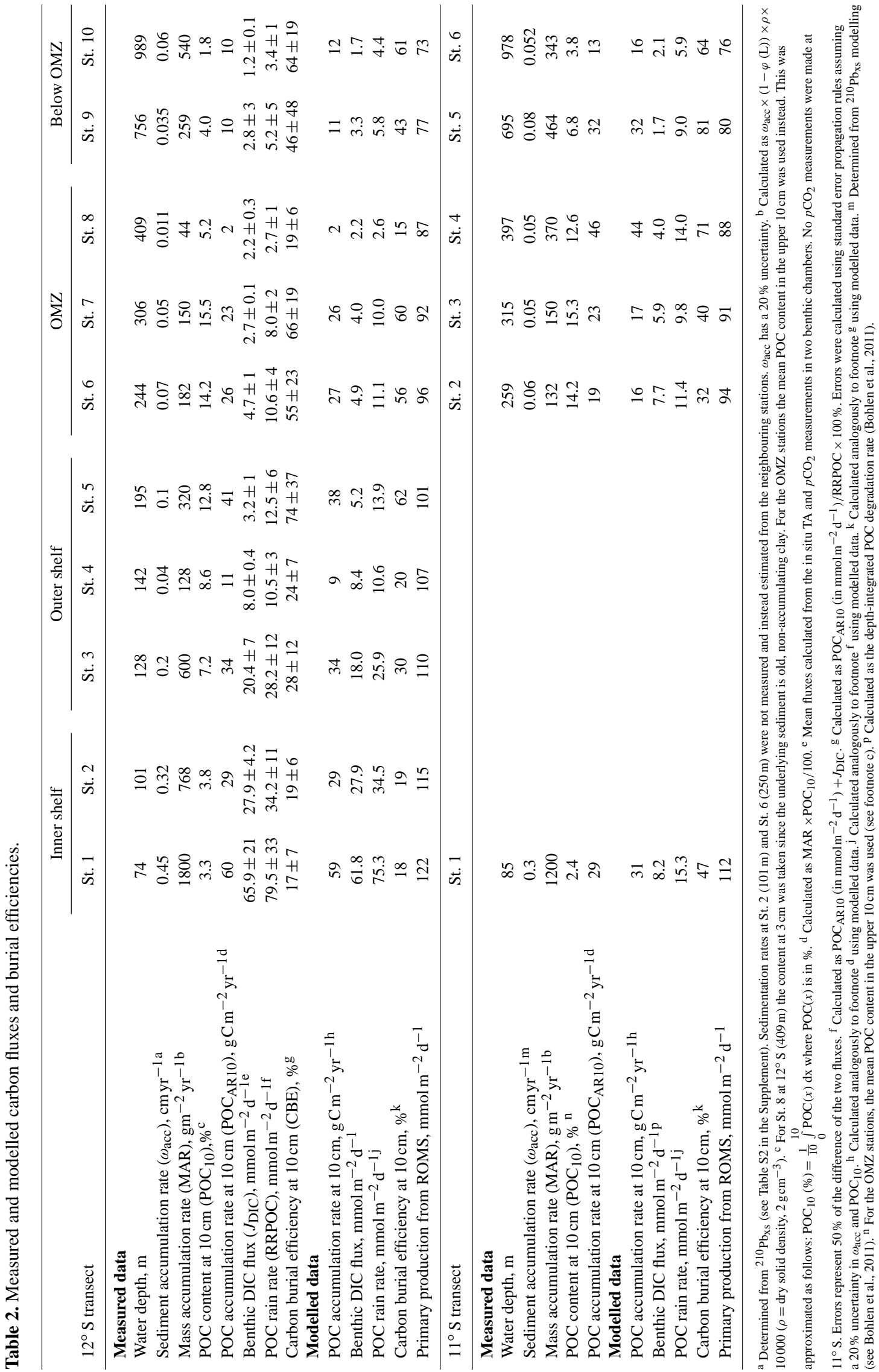


3-4 times higher than the global shelf average of $500 \mathrm{~g} \mathrm{~m}^{-2}$ $\mathrm{yr}^{-1}$ (Burwicz et al., 2011). They corresponded to sedimentation rates $\left(\omega_{\text {acc }}\right)$ of 0.45 and $0.3 \mathrm{~cm} \mathrm{yr}^{-1}$ (Table 2). Beyond the middle shelf, MAR decreased sharply to 132 and $44 \mathrm{~g} \mathrm{~m}^{-2} \mathrm{yr}^{-1}$ at St. $2\left(11^{\circ} \mathrm{S}\right)$ and St. $8\left(12^{\circ} \mathrm{S}\right)$, respectively. These latter values are associated with measurable ${ }^{210} \mathrm{~Pb}_{\mathrm{xs}}$ in the upper $3 \mathrm{~cm}$ only and thus indicative of sediment winnowing or resuspension, as mentioned above. A relatively low MAR of $128 \mathrm{~g} \mathrm{~m}^{-2} \mathrm{yr}^{-1}$ was also determined for St. 4 at $12^{\circ} \mathrm{S}$ compared to the neighbouring stations. MAR and $\omega_{\text {acc }}$ tended to be higher at the deep oxygenated stations compared to the OMZ stations, with $\omega_{\text {acc }}$ of $0.06 \mathrm{~cm} \mathrm{yr}^{-1}$ at St. 10 $\left(12^{\circ} \mathrm{S}\right)$ and $0.05 \mathrm{~cm} \mathrm{yr}^{-1}$ at St. $5\left(11^{\circ} \mathrm{S}\right)$. Aluminium accumulation showed similar trends to MAR, with highest values on the shelf and a pronounced increase below the OMZ (Fig. 3b). For some cores, peaks in ${ }^{241} \mathrm{Am}$ activities could be detected, which provide independent validation of $\omega_{\text {acc }}$ derived from the ${ }^{210} \mathrm{~Pb}_{\mathrm{xs}}$ systematics (Fig. 2 and Appendix A).

\subsection{Geochemistry}

Dissolved $\mathrm{O}_{2}$ concentrations in the water column reveal the vertical extent of the $\mathrm{OMZ}$ and the presence of oxygendeficient water overlying the upper slope sediments at both latitudes (Fig. 1). Qualitatively, geochemical solute profiles in the sediments from 11 and $12^{\circ} \mathrm{S}$ are typical for continental margin settings (Bohlen et al., 2011; Fig. 4). The model was able to accurately simulate the geochemical profiles along both transects. Sediment porewater concentrations of $\mathrm{NH}_{4}^{+}$ and alkalinity were highest on the shelf and decreased with water depth. Conversely, $\mathrm{SO}_{4}^{2-}$ depletion was more extensive at the shallower stations. $\mathrm{SO}_{4}^{2-}$ also showed a much stronger depletion on the shelf at $12^{\circ} \mathrm{S}$ compared to $11^{\circ} \mathrm{S}$, leading to the formation of a methanogenic layer below $65 \mathrm{~cm}$. These trends confirm general expectations that less reactive organic material reaches the seafloor as water depth increases (e.g. Suess, 1980; Levin et al., 2002).

\subsection{Organic carbon distributions and burial rates}

Surface POC content at $12^{\circ} \mathrm{S}$ was lowest (ca. $5 \%$ ) on the middle shelf and below the OMZ (Fig. 4). At these stations, POC decreased in the upper $10 \mathrm{~cm}$ and reached asymptotic values at around $10 \mathrm{~cm}$, where refractory components dominated (Reimers and Suess, 1983a). PON showed the same qualitative trends. Maximal POC contents of ca. $17 \%$ were measured inside the $\mathrm{OMZ}$ and are typical for the Peruvian margin (Suess, 1981). Here, POC showed a marked change at around 15 to $20 \mathrm{~cm}$ depth (Fig. 4). This may reflect the regime shift in the Peruvian OMZ during the Little Ice Age circa $1820 \mathrm{AD}$, caused by a northward displacement of the Intertropical Convergence Zone (Gutiérrez et al., 2009). These features were also present at St. 4 and 5 on the outer shelf. The steady-state model does not capture centennial changes in the OMZ conditions suggested by the POC

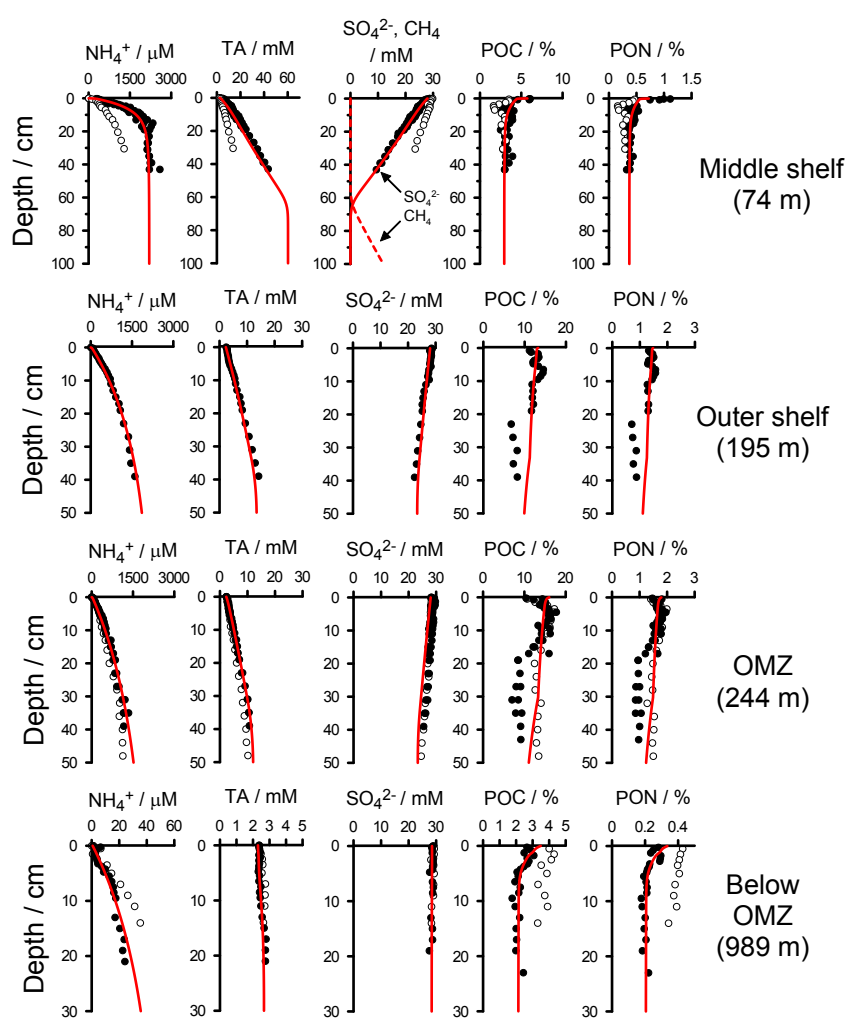

Figure 4. Dissolved and solid phase biogeochemical data for sediment cores from $12^{\circ} \mathrm{S}$ (filled symbols) with model simulation results (red curves). Four sites are chosen to exemplify the general trends on the middle shelf (St. 1, $74 \mathrm{~m}$ ), outer shelf (St. 5, $195 \mathrm{~m}$ ), OMZ (St. 6, $244 \mathrm{~m}$ ) and below the OMZ (St. 10, $989 \mathrm{~m}$ ). The full set of data and model results is given by Dale et al. (unpub. data). Also shown (open symbols) are data from three sites along $11^{\circ} \mathrm{S}$ (St. 1 (85 m), 3 (315 m) and 6 (978 m); Bohlen et al., 2011). For clarity, the simulation curves from $11^{\circ} \mathrm{S}$ have been omitted and are presented in Bohlen et al. (2011). POC and PON distributions were not shown in that study and are shown for the first time here.

profiles. Very similar trends were observed at $11^{\circ} \mathrm{S}$, implying that organic matter distributions are qualitatively and quantitatively driven by the same first-order processes at both latitudes.

POC accumulation rates for the middle shelf and deep stations were calculated from the mass accumulation rates and POC content at $10 \mathrm{~cm}$ (Table 2). Due to recent variations in POC content for the OMZ stations, the average POC content in the upper $10 \mathrm{~cm}$ was used. For St. 8 at $12^{\circ} \mathrm{S}(409 \mathrm{~m})$, POC accumulation was calculated at $3 \mathrm{~cm}$, since the underlying sediment was old, non-accumulating clay. The highest carbon accumulation rates were calculated for the middle shelf at $12^{\circ} \mathrm{S}\left(60 \mathrm{~g} \mathrm{~m}^{-2} \mathrm{yr}^{-1}\right.$; Table 2). POC accumulation generally decreased with increasing water depth at $12^{\circ} \mathrm{S}$ with relatively low values at St. $4\left(11 \mathrm{~g} \mathrm{~m}^{-2} \mathrm{yr}^{-1}\right)$ and St. 8 $\left(2 \mathrm{~g} \mathrm{~m}^{-2} \mathrm{yr}^{-1}\right)$. Accumulation rates were more variable for the $11^{\circ} \mathrm{S}$ transect. 
Table 3. Mean rates of organic carbon accumulation and primary production on the Peruvian margin from this study compared to global averages by Burdige (2007) and Sarmiento and Gruber (2006). Units: $\mathrm{mmol} \mathrm{m}^{-2} \mathrm{~d}^{-1}$.

\begin{tabular}{lrrrc}
\hline & $11^{\circ} \mathrm{S}$ & $12^{\circ} \mathrm{S}$ & Burdige & Sarmiento and \\
\hline & & & $(2007)^{\mathrm{a}}$ & Gruber $(2006)^{\mathrm{b}}$ \\
\hline POC accumulation & & & & \\
Shelf (0-200 m) & 13.8 & 9.9 & 4.0 & - \\
Upper slope (200-1000 m) & 7.2 & 2.8 & 1.0 & - \\
Total margin (0-1000 m) & 6.8 & 6.1 & $2.9(1.2)$ & 1.4 \\
Primary production $(0-1000 \mathrm{~m})$ & $250-400^{\mathrm{c}}$ & - & 71 & \\
\hline
\end{tabular}

${ }^{a}$ From Tables 4 and 5 in Burdige (2007) based on a large number of independent studies. The number in parentheses considers low POC burial rates in sandy sediments. ${ }^{\mathrm{b}}$ From Table 6.5 .1 in that study. ${ }^{\mathrm{c}}$ Range based on previous reports (Walsh, 1981; Quiñones et al., 2010 and references therein).
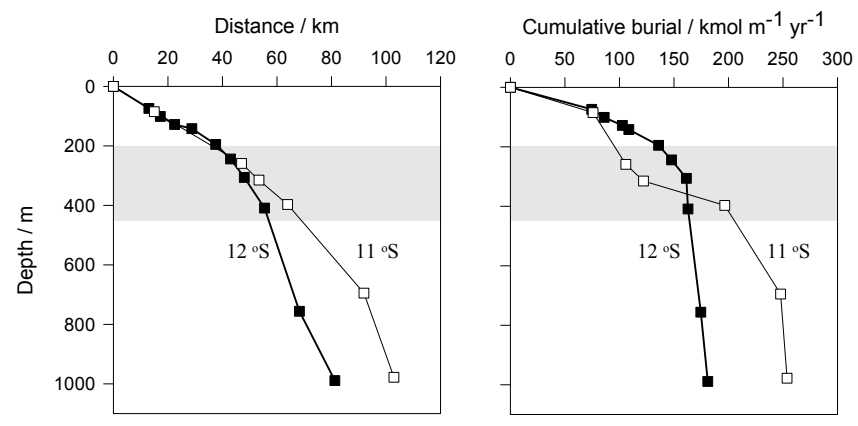

Figure 5. (a) Distance from the coastline versus water depth, and (b) cumulative organic carbon burial at $10 \mathrm{~cm}$ depth, $\left(\mathrm{POC}_{10}\right.$, measured data, Table 2) along the two transects. The grey shade highlights the OMZ stations (ca. 200 to $450 \mathrm{~m}$ ).

Cumulative POC burial rates across the margin in Fig. 5b were calculated by integrating the measured POC accumulation at each station over the distance between stations in Fig. 5a. POC burial increased sharply on the middle shelf to ca. $100 \mathrm{~m}$ at both latitudes, at which point the rates diverged to give higher burial at $12^{\circ} \mathrm{S}$ down to the lower edge of the OMZ. Burial at $11^{\circ} \mathrm{S}$ amounted to $254 \mathrm{kmol} \mathrm{C} \mathrm{m}^{-1} \mathrm{yr}^{-1}$ (per metre of coastline). A lower value of $181 \mathrm{kmol} \mathrm{C} \mathrm{m}^{-1} \mathrm{yr}^{-1}$ was calculated for $12^{\circ} \mathrm{S}$, possibly due to the steeper slope down to ca. $1000 \mathrm{~m}$. Mean POC burial on the margin, calculated by dividing the total cumulative burial by the transect length, was $6.8\left(11^{\circ} \mathrm{S}\right)$ and $6.1 \mathrm{mmol} \mathrm{C} \mathrm{m}^{-2} \mathrm{~d}^{-1}\left(12^{\circ} \mathrm{S}\right)$. This compares to a range of 1.2 to $2.9 \mathrm{mmol} \mathrm{C} \mathrm{m}^{-2} \mathrm{~d}^{-1}$ for the average continental margin (Table 3 ).

\subsection{DIC fluxes}

Measured DIC fluxes were high on the middle shelf $\left(65.9 \mathrm{mmol} \mathrm{m}^{-2} \mathrm{~d}^{-1}\right)$ and decreased quasi-exponentially with depth (Table 2). DIC fluxes were low in the OMZ at $12^{\circ} \mathrm{S}\left(2.2-4.7 \mathrm{mmol} \mathrm{m}^{-2} \mathrm{~d}^{-1}\right)$ and similar to the deep sites $\left(1.2-2.8 \mathrm{mmol} \mathrm{m}^{-2} \mathrm{~d}^{-1}\right)$. Measured DIC in the benthic chambers was assumed to originate entirely from POC mineralisation. There was no clear increase or decrease in $\mathrm{Ca}^{2+}$ and $\mathrm{Mg}^{2+}$ concentration in the benthic chambers that would indicate an important role for carbonate precipitation/dissolution (data not shown). This is also inferred from porewater gradients of $\mathrm{Ca}^{2+}$ and $\mathrm{Mg}^{2+}$ (Fig. S3). $\mathrm{Ca}^{2+}$ and $\mathrm{Mg}^{2+}$ fluxes show that the potential contribution of carbonate precipitation was $<5 \%$ of the DIC flux across all stations. This is well within the error of the DIC flux (Table 2), such that carbonate precipitation can be ignored for all practical purposes.

Modelled DIC concentrations inside the benthic chambers at $12^{\circ} \mathrm{S}$ showed good agreement with those calculated from measured TA and $p \mathrm{CO}_{2}$ concentrations (Fig. S2). Measured and modelled fluxes agreed to within $\pm 50 \%$, but most stations were simulated to within $\pm 20 \%$ or better (Fig. 6a). It should be remembered that the model is not only constrained by the DIC fluxes but also by porewater distributions and benthic DIN and $\mathrm{O}_{2}$ fluxes (Bohlen et al., 2011). Thus, whilst the modelled DIC fluxes could be improved, they form only one aspect of the overall goodness-of-fit to the observed database. In general, the agreement between the modelled and measured DIC fluxes affords confidence in the modelled DIC fluxes at $11^{\circ} \mathrm{S}$ where in situ $p \mathrm{CO}_{2}$ measurements were not made (Table 2). The simulated DIC fluxes at $11^{\circ} \mathrm{S}$ showed the same trends as $12^{\circ} \mathrm{S}$, although the flux on the middle shelf $\left(8.2 \mathrm{mmol} \mathrm{m}^{-2} \mathrm{~d}^{-1}\right)$ was a factor of 8 smaller.

\subsection{Organic carbon burial efficiency (CBE)}

At each station, $\mathrm{CBE}(\%)$ was calculated as POC accumulation rate $\div$ (POC accumulation rate + DIC flux $) \times 100 \%$ (Table 2). Measured and modelled $\mathrm{CBE}$ at $12^{\circ} \mathrm{S}$ showed very good agreement (Fig. 6b). Low CBEs of $19 \pm 6 \%$ to $28 \pm 12 \%$ were derived for St. 1 to 4 on the shelf. This contrasts with the elevated POC accumulation rates, but is in agreement with the high DIC fluxes (Fig. 6a). Low CBE of $19 \pm 6 \%$ were also observed at the $409 \mathrm{~m}$ site where winnowing is suspected to occur. Relatively high CBEs were calculated at St. 5 to 7 in mid-water depth range of ca. 200 to 

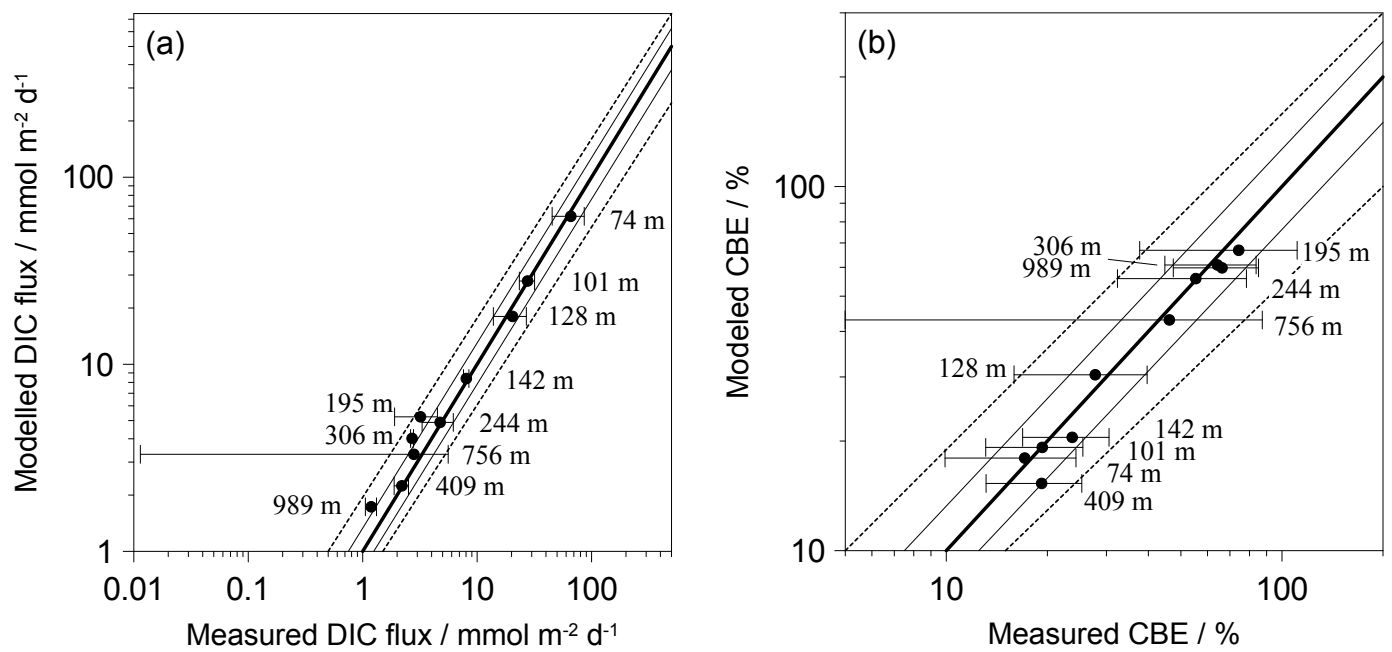

Figure 6. Measured versus modelled (a) DIC fluxes and (b) carbon burial efficiencies $(\mathrm{CBE})$ at $12^{\circ} \mathrm{S}$. The error bars are the uncertainties in Table 2. The thick solid line is the $1: 1$ curve. The thin solid lines and dashed lines denote \pm 25 and $\pm 50 \%$ limits on the $1: 1$ correlation, respectively. The uncertainty in the measured DIC fluxes is equal to $50 \%$ of the difference of the two fluxes measured during each lander deployment, that is, due to seafloor heterogeneity. This leads to a mean relative error in DIC flux of 20 to $30 \%$ at $12^{\circ} \mathrm{S}$. The uncertainty in the $\mathrm{CBE}$ is calculated by the propagation of errors in DIC flux and POC burial (Table 2).

$300 \mathrm{~m}(55 \pm 23 \%$ to $74 \pm 37 \%)$ and at the deep oxygenated sites $(46 \pm 48 \%$ to $64 \pm 19 \%)$. At $11^{\circ} \mathrm{S}$, model-derived CBE showed broadly similar trends, although the CBE at the shelf station was higher (47\%). The highest CBE of $81 \%$ was calculated for the $695 \mathrm{~m}$ station $\left(11^{\circ} \mathrm{S}\right)$ in oxygen-deficient waters $\left(\mathrm{O}_{2}<20 \mu \mathrm{M}\right)$ below the OMZ. A detailed discussion of the uncertainties in the $\mathrm{CBE}$ estimates is provided in Appendix A.

\subsection{Primary production and organic carbon rain rate}

Primary production (PP) estimates from the ROMSBioEBUS model for 11 and $12^{\circ} \mathrm{S}$ are shown in Fig. 7. The data represent the annual mean \pm s.d. for the locations close to where BIGO landers were deployed. Diatoms dominated the PP at both latitudes, with rates decreasing offshore from ca. $110 \mathrm{mmol} \mathrm{m}^{-2} \mathrm{~d}^{-1}$ at the shallowest site to ca. $80 \mathrm{mmol} \mathrm{m}^{-2} \mathrm{~d}^{-1}$ at the deepest site. The model revealed a much larger intra-annual variability ranging from ca. 70 to $170 \mathrm{mmol} \mathrm{m}^{-2} \mathrm{~d}^{-1}$ with highest values in austral summer (see Fig. S4).

Organic carbon rain rates to the seafloor (RRPOC) were calculated as the sum of the benthic carbon oxidation rate (i.e. DIC flux) and POC accumulation (Table 2). For the 11 and $12^{\circ} \mathrm{S}$ transects, the modelled and measured DIC fluxes were used, respectively. RRPOC showed a rapid decrease on the shelf stations at $12^{\circ} \mathrm{S}$ with a more attenuated decrease with depth (Fig. 7a). Station $8(409 \mathrm{~m})$ at $12^{\circ} \mathrm{S}$ is again an exception due to the low POC accumulation there. At $11^{\circ} \mathrm{S}$ the trends were not so obvious due to fewer sampling stations (Fig. 7b). The fraction of PP reaching the sediment was highest at the shallowest station at $12^{\circ} \mathrm{S}(65 \%)$, decreasing to $<12 \%$ at the $\mathrm{OMZ}$ and deep stations (Fig. 7c).

\section{Discussion}

\subsection{Spatial patterns of organic carbon preservation}

Fine-grained continental margin sediments in the modern ocean $(<1000 \mathrm{~m})$ account for $70-85 \%$ of global POC burial (Hedges and Keil, 1995; Burdige, 2007). The mean global POC burial flux on the margin $\left(1.2\right.$ to $\left.2.9 \mathrm{mmol} \mathrm{C} \mathrm{m}^{-2} \mathrm{~d}^{-1}\right)$ is equivalent to around $3 \%$ of primary production (Table 3 ). Although the POC burial flux on the Peruvian margin is far higher, it accounts for a similar fraction of primary production, thus implying a lack of preferential carbon burial compared to the average continental margin. However, the CBE reveals interesting spatial trends in carbon preservation that are not discernible by comparison of mean burial fluxes.

Previously published CBEs for a range of marine environments show a positive dependency on sedimentation accumulation rate (Fig. 8). This arises because sediment accumulation is intrinsically linked to carbon burial flux, which itself is strongly tied to rain rate (Müller and Suess, 1979). In addition, sediments underlying oxygen-deficient waters $\left(\mathrm{O}_{2}<20 \mu \mathrm{M}\right)$ appear to have a higher CBE than those deposited under oxygenated bottom waters. Data from Peru seaward of the shelf agree with this idea (red stars, Fig. 8). However, the CBE above and below the OMZ is inconsistent with the existing database. Firstly, CBEs for the anoxic shelf (blue stars) plot within the range for normal oxic conditions instead of $>50 \%$ expected for the oxygen-depleted condi- 

(a) Primary production (ROMS)
$\square$ Rain rate (from benthic measurements)
$\star$ POC accumulation $(10 \mathrm{~cm})$

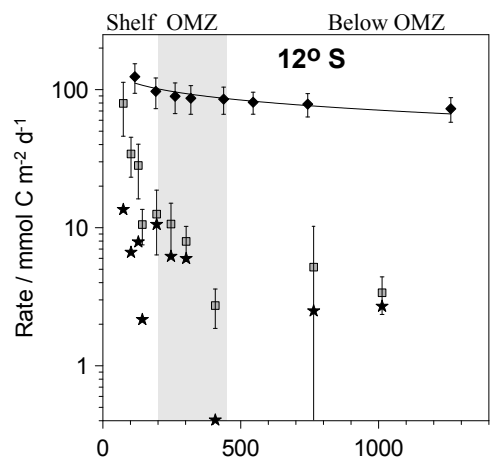

(b) Primary production (ROMS) $\square$ Rain rate (from benthic model) $\star$ POC accumulation $(10 \mathrm{~cm})$

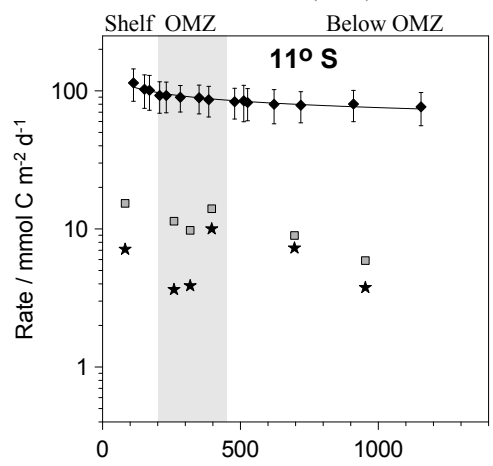

(c)

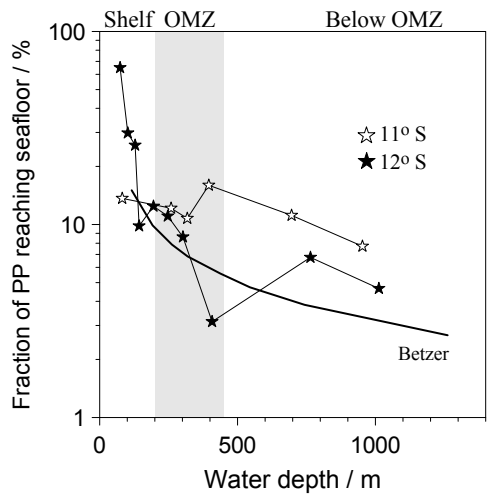

Figure 7. (a) Mean annual primary production ( \pm s.d.) for the $12^{\circ} \mathrm{S}$ transect calculated by the ROMS-BioEBUS model (diamonds). Rain rates to the seafloor (squares) and POC accumulation rates at $10 \mathrm{~cm}$ (stars) were estimated using the benthic measurements (Table 2). The solid line is a power law regression through the PP data. (b) As (a) for $11^{\circ} \mathrm{S}$, except that rain rate is the modelled data. (c) Fraction of PP that reaches the seafloor calculated by dividing the rain rate by the PP calculated from the regression curve. The solid line is the predicted fraction at $12^{\circ} \mathrm{S}$ according to the empirical function of Betzer et al. (1984). The fraction for $11^{\circ} \mathrm{S}$ differs by a few percent only (omitted for clarity). The grey shade highlights the OMZ stations (ca. 200 to $450 \mathrm{~m}$ ).

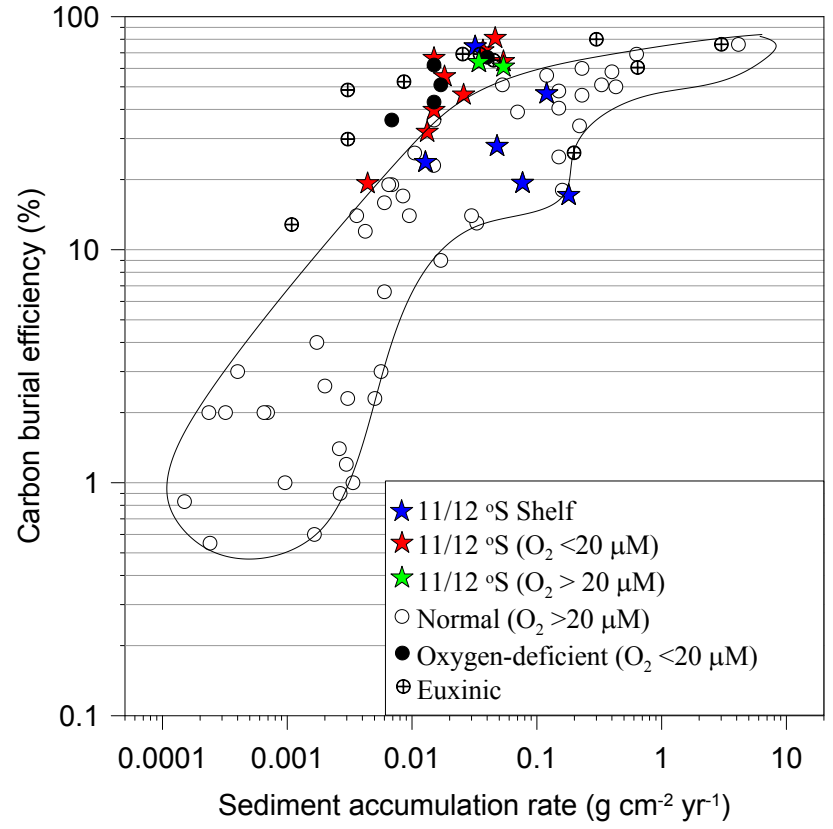

Figure 8. Carbon burial efficiency versus bulk sediment accumulation rate in contemporary ocean sediments. Open and filled circles represent sites from studies with bottom water $\mathrm{O}_{2}>20$ and $<20 \mu \mathrm{M}$, respectively; the former enclosed by the solid line (Canfield, 1993, 1994; Burdige, 2007; Hartnett and Devol, 2003; Reimers et al., 1992). Euxinic settings are also indicated. Stars are data from this study for $11^{\circ} \mathrm{S}$ (modelled data) and $12^{\circ} \mathrm{S}$ (measured data). Blue stars indicate sites on the shelf, which mostly have lower-than-expected CBE compared to the existing database. The two green stars correspond to the deep oxygenated sites $\left(\mathrm{O}_{2}>20 \mu \mathrm{M}\right)$ with higher-than-expected CBE. Red show the expected elevated CBEs for low oxygen environments.

tions encountered. The $195 \mathrm{~m}$ site located on the shelf break is an exception, although the CBE does have high uncertainty $(74 \pm 37 \%)$. In agreement, Reimers and Suess (1983a) also estimated a rather low CBE of 16 to $38 \%$ on the outer shelf break at $11^{\circ} \mathrm{S}$ (186 m depth). Secondly, sediments underlying oxygenated bottom waters $\left(\mathrm{O}_{2}>20 \mu \mathrm{M}\right)$ below the OMZ have a higher-than-expected CBE (green stars) and plot alongside those from oxygen-deficient and euxinic waters. These discrepancies are the focus of the following discussion.

\subsubsection{Low CBE on the shelf}

Our low calculated shelf CBEs imply that POC is preferentially degraded there, relative to deeper sites. Trends in sediment grain size and POC content support this basic idea. The fine-grained sediment fraction (clay plus silt) at $11^{\circ} \mathrm{S}$ is $>80 \%$ on the shelf and decreases to ca. $60 \%$ below the OMZ due to increasing fractions of coarser particles (Mosch et al., 2012). Given that POC content correlates inversely with grain size (Mayer, 1994; Bergamaschi et al., 1997), 
higher contents would be predicted on the shelf relative to the OMZ. Yet, POC is $<5 \%$ in shallower waters and $>15 \%$ in the OMZ (Fig. 4). We can therefore assume that the ratio of organic carbon to particle surface area (OC / SA) is likely to be lower on the shelf compared to the OMZ. Low OC / SA ratios indicate organic matter in a more advanced state of diagenetic alteration (Keil et al., 1994, Mayer, 1994; Hedges et al., 1999). We can be confident that the OC / SA ratio is largely unaffected by differences in the structural composition and reactivity of POC, since organic matter on the margin is almost entirely marine-derived (Arthur et al., 1998; Reimers and Suess, 1983b). The evidence suggests that benthic mineralisation is more complete on the shelf compared to the OMZ.

Results from biochemical studies dovetail with this idea. Spatial differences in the quality of organic matter on the shelf and slope have been described (Levin et al., 2002; Niggemann and Schubert, 2006; Lomstein et al., 2009). These workers found the highest amino acid content of sedimentary organic matter (i.e. "fresher" material) on the outer shelf and within the OMZ (ca. $130-360 \mathrm{~m}$ ). Relatively low values were reported for the middle shelf, indicating more degraded material. Sediments from the Arabian Sea OMZ are also enriched in high-quality hydrolysable amino acids (Koho et al., 2013). Similarly, more extensive diagenetic alteration of organic matter on the Peru shelf relative to the OMZ has been inferred from the amino acid degradation index (Lomstein et al., 2009). Enhanced carbon preservation in the OMZ has been noted previously, and detected as the formation of insoluble humin termed "proto-kerogen" (Reimers and Suess, 1983a, b). Considering these results collectively, the low POC content and CBE on the shelf seem to be rooted in the quality of buried material.

Prolonged exposure of sediments to $\mathrm{O}_{2}$ strongly modulates amino acid and aldose distributions in sediments, thereby decreasing the quality and quantity of buried organic matter (Hedges et al., 1999). Furthermore, OC / SA ratios and $\mathrm{CBE}$ are inversely correlated with the oxygen exposure time (OET) of organic matter (Hartnett et al., 1998; Hedges et al., 1999). Whilst the significance of bottom water $\mathrm{O}_{2}$ on carbon preservation remains controversial (Demaison and Moore, 1980; Pedersen and Calvert, 1990; Canfield, 1994; Hedges and Keil, 1995; Hulthe et al., 1998; Burdige, 2007), the presence of $\mathrm{O}_{2}$ could explain the low OC / SA ratios and CBEs on the Peruvian shelf in a similar way as described for the Arabian Sea OMZ (Keil and Cowie, 1999). Although shelf bottom waters were anoxic at the time of sampling, periodic intrusions of oxygenated water occasionally lead to a deepening of the upper edge of the OMZ to $200 \mathrm{~m}$ or more (e.g. Levin et al., 2002). The frequency and duration of these episodes can be several months, driven by seasonal and subseasonal anomalies in oceanographic conditions such as positive ENSO periods and the passage of coastal trapped waves (Gutiérrez et al., 2008). During these events, bottom water $\mathrm{O}_{2}$ concentrations can vary by several tens of $\mu \mathrm{M}$ within days or weeks (Gutiérrez et al., 2008), leading to an increase in the OET of organic matter.

Oxygenation is followed by an increase in macrozoobenthos species richness, density, bioturbation potential, and the construction of sediment burrows and galleries that could further increase the OET of organic matter (Tarazona et al., 1988; Gutiérrez et al., 2008). This has been observed offshore Chile, where prolonged ventilation leads to a switch in the polychaete assemblage from tube-dwelling, interface feeders to burrowing, deposit feeders (Gutiérrez et al., 2008; Sellanes et al., 2007). This sequence of events likely explains the non-zero bioturbation coefficients on the shelf (Table S2). It also fits with the previous biochemical data, since sediments with episodic exposure to $\mathrm{O}_{2}$ tend to display biogeochemical characteristics of permanently oxic settings (Aller, 1994). Redox oscillations caused by the arrival of burrowing animals may further enhance mineralisation of refractive organic compounds via priming or co-oxidation pathways, leading to a further reduction in CBE (Aller, 1998; Canfield, 1994; Hulthe et al., 1998). On the basis of the information currently available, therefore, we argue that occasional bathing of shelf sediments with oxygenated bottom waters is a determining, if not dominating, factor driving the low CBE observed there.

\subsubsection{High CBE below the OMZ}

Oceanographic conditions below the OMZ are relatively quiescent and more conducive to steady-state diagenesis (Scholz et al., 2011). The OET of organic matter in sediments at the deepest sites was calculated by dividing the $\mathrm{O}_{2}$ penetration depths by the ${ }^{210} \mathrm{~Pb}_{\mathrm{xs}}$-derived sediment accumulation rates. Penetration depths calculated using the relation of Cai and Sayles (1996) were $4 \mathrm{~mm}$ at $11^{\circ} \mathrm{S}$ (St. 6) and $7 \mathrm{~mm}$ at $12^{\circ} \mathrm{S}$ (St. 10). The corresponding OETs are 8 and 12 years (respectively). An empirical relationship between CBE and OET derived for a range of marine settings predicts a $\mathrm{CBE}$ of around $20 \%$ for these OETs, although there is considerable uncertainty associated with this trend (Hartnett et al., 1998). This is similar to the normal oxic settings in Fig. 8 and much lower than the determined value of $>60 \%$. Hence, factors other than the OET of carbon in the sediment must influence the $\mathrm{CBE}$ at the deep sites.

Our CBE calculations at the deep sites may be influenced by lateral particle transport and sediment mobilisation by current-induced resuspension. The increase in sediment mass and aluminium accumulation below the OMZ suggests that terrestrial lithogenic material is preferentially deposited there. The shelf area between 6 and $10^{\circ} \mathrm{S}$ is a major area of sediment reworking and winnowing by the poleward-flowing Peru Undercurrent with average near-bottom velocities of 8$9 \mathrm{~cm} \mathrm{~s}^{-1}$ (Suess et al., 1987; Chaigneau et al., 2013). Finegrained biogenic debris from this area may undergo multiple deposition/resuspension cycles as it is redistributed down the slope in the benthic boundary layer in a southerly direction 
(Krissek et al., 1980; Suess et al., 1987; Kim and Burnett, 1988; Arthur et al., 1998). Furthermore, sediment winnowing at 11 and $12^{\circ} \mathrm{S}$ occurs in discrete depth intervals in the depth range between 400 and $800 \mathrm{~m}$ due to the presence of near-critical topographic slopes (e.g. Mosch et al., 2012). At near-critical slopes, internal waves can resuspend sediment through the generation of bores from internal tides, which is then transported upslope or downslope (Hosegood and van Haren, 2004; Martini et al., 2013). This is identifiable from the low mass accumulation rates at St. 8 at $12^{\circ} \mathrm{S}$ (Table 2) and the characteristic presence of foraminiferal sands and phosphorites that form under these conditions (Glenn and Arthur, 1988; Reimers and Suess, 1983b; Arthur et al., 1998; Mosch et al., 2012). Non-linear internal wave trains have also been observed on the shelf at 11 and $12^{\circ} \mathrm{S}$ causing short pulses of elevated near-bottom velocities (Sommer et al., 2014). It is thus not unreasonable to argue that sediment winnowing higher up on the slope contributes to the sediment that accumulates below the OMZ. In that case, the OET of organic matter would be enhanced during transit in the benthic boundary layer. Consequently, POC deposited at the deeper sites investigated in this study is likely to be in a more advanced state of degradation than particles that settle vertically, thereby leading to CBEs that are apparently elevated. Arthur et al. (1998) argued along similar lines to explain the presence of highly degraded organic matter at sites close to ours. Unusually high CBEs in the southern California basins suggest that particle transport mechanisms may play a wider role in carbon preservation patterns in slope sediments (Berelson et al., 1996).

\subsection{Carbon mineralisation in the water column}

A comparison of the rain rate and PP estimates from the ROMS-BioEBUS model shows that only a minor fraction of PP reaches the seafloor beyond the middle shelf (Fig. 7c). The true fraction may be even lower since modelled PP is 2 to 3 times below the range of 250 to $400 \mathrm{mmol} \mathrm{m}^{-2} \mathrm{~d}^{-1}$ reported previously (Walsh, 1981; Quiñones et al. 2010 and references therein). Robust PP estimates close to the coastline are impeded by the relatively coarse spatial resolution $\left(1 / 9^{\circ}\right)$ in the model which cannot accurately resolve nearshore processes. The model also represents climatological conditions (i.e. interannual steady state), whereas PP during neutral or cold (La Niña) ENSO phases (this study) may deviate from the mean value (Ryan et al., 2006). Nonetheless, based on the data in Fig. 7c, it appears that the Peruvian margin broadly behaves as an open ocean setting when compared to existing empirical relationships relating PP to rain rate (e.g. Betzer et al., 1984).

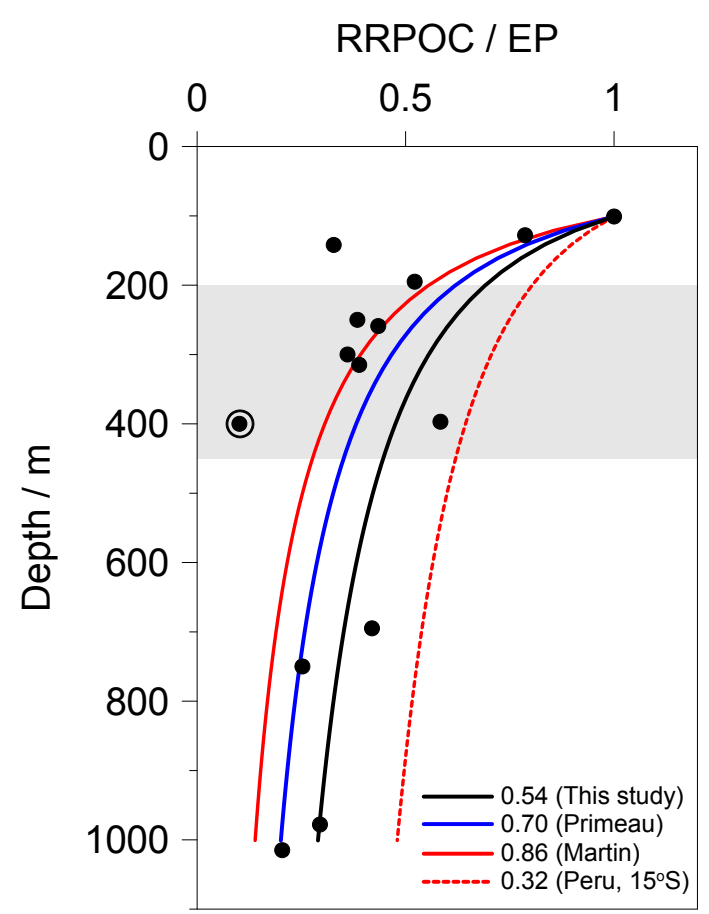

Figure 9. Fraction of export production reaching the seafloor at 11 and $12^{\circ} \mathrm{S}$ (circles) referenced to the datum at $101 \mathrm{~m}$, where RRPOC $=$ DIC flux + POC burial. The black line is the best-fit curve (Eq. 8) with an attenuation coefficient of $b=0.54$. The datum from St. 8 (circled) is not included in the regression (see text). The blue and red lines show the open-ocean attenuation coefficients derived by Primeau (2006) and Martin et al. (1987), whereas the dashed red line corresponds to sediment trap data offshore of Peru at $15^{\circ} \mathrm{S}(b=0.32$, Martin et al., 1987), all normalised to unity. The grey shade highlights the OMZ stations (ca. 200 to $450 \mathrm{~m}$ ).

The rate at which organic matter is respired during transit through the water column is usually calculated using sediment trap data (Martin et al., 1987). The unrespired fraction of export production has been widely described using the following function:

$F(z) / \mathrm{EP}=(z / 100)^{-b}$,

where EP is the export production, typically defined at $100 \mathrm{~m}, F(z)$ is the sinking flux at depth, $z(\mathrm{~m})$, below $100 \mathrm{~m}$, and $b$ is the dimensionless attenuation coefficient (Martin et al., 1987). Low $b$ indicates slow degradation in the water column and a high fraction of export production reaching the sediment and vice-versa. A mean $b$ of 0.86 for oxic openocean waters was derived by Martin et al. (1987), which is similar to the $0.82 \pm 0.16$ quoted by Berelson (2001) for a range of marine settings. Primeau (2006) proposed a lower $b$ of $0.70 \pm 0.08$ based on a reanalysis of Berelson's data. A recent study in the North Atlantic using free-drifting sediment traps also reported a $b$ of 0.70 (Giering et al., 2014). 
We estimated $b$ by fitting the calculated rain rates at 11 and $12^{\circ} \mathrm{S}$ to the following function analogous to Eq. (7):

$\operatorname{RRPOC}(z) / \mathrm{EP}=(z / 101)^{-b}$.

The EP was determined at each station individually by multiplying the PP estimate from the pelagic model by the ratio of particle export to primary production ( $p e$ ratio, Dunne et al., 2005). The pe ratio was assumed to be constant across the margin and was calculated as PP / RRPOC using data from St. $2\left(12^{\circ} \mathrm{S}\right)$. This station was taken as the reference point since the water depth $(101 \mathrm{~m})$ is approximately $100 \mathrm{~m}$. The derived pe ratio was 0.26 ; consistent with observations that most PP in the Humboldt system is mineralised in the surface mixed layer under non-El-Niño conditions (Quiñones et al. 2010 and references therein). The two shallowest stations with water depth $<101 \mathrm{~m}$ were excluded from the analysis in addition to St. 8 since, as mentioned, we suspect that sediment resuspension by the bottom currents is important there. To offset the potential bias in our RRPOC estimates due to seasonal variability in primary production, the PP was averaged over the period corresponding to the cruise and 1 month previously. (see Appendix).

The best fit to Eq. (8) shown in Fig. 9 was obtained with $b=0.54 \pm 0.14$ (NonlinearModelFit function in MATHEMATICA). The $b$ value considering data from $12^{\circ} \mathrm{S}$ only is $0.85 \pm 0.25$ (the result for $11^{\circ} \mathrm{S}$ is not statistically significant at the $95 \%$ level). Our derived $b$ coefficients thus tend toward the higher open-ocean composite estimates of Martin (1987) and Primeau (2006). Yet, previous studies indicate that respiration of organic matter is significantly reduced in oxygen-deficient water columns (Martin et al., 1987; Devol and Hartnett, 2001; Van Mooy et al., 2002). For example, a $b$ of 0.32 was determined for the Peruvian OMZ at $15^{\circ} \mathrm{S}$ using sediment trap data (Martin et al., 1987). Devol and Hartnett (2001) calculated a value of 0.36 for the Mexican margin using benthic carbon oxidation rates and burial fluxes. This agrees with 0.40 derived using moored sediment trap data from the same location (Van Mooy et al., 2002). These workers supported their fieldwork with laboratory experiments showing that natural particulate material collected at the base of the euphotic zone was degraded less efficiently under anoxic versus oxic conditions. A notable exception to these studies is the $b$ value of 0.79 derived for the Arabian Sea OMZ using sediment traps (Berelson, 2001). Nonetheless, based on these findings, a much lower $b$ coefficient for our composite data set may have been expected.

We propose that the high $b$ determined in this study is attributed to the multiple resuspension/deposition of slope sediments by internal waves discussed above. Resuspension enhances the particle residence time in the water column and shifts the site of labile POC mineralisation away from the sediments. This will reduce the benthic DIC flux and thus lower the calculated RRPOC. This explanation is consistent with unusually high $\mathrm{CBE}$ below the OMZ. The low rain rate calculated for St. 8 at $12^{\circ} \mathrm{S}$ further exemplifies the importance of sediment reworking on the calculated rain rates (Fig. 8). By implication, particle transport on the Mexican margin and at the deep offshore station at Peru $\left(15^{\circ} \mathrm{S}\right)$ is more controlled by vertical settling, resulting in shorter residence times and enhanced carbon preservation through the water column. The good agreement between the $b$ coefficients determined independently by traps and benthic data from Mexico supports this idea (Devol and Hartnett, 2001; Van Mooy et al., 2002). In contrast, the latitudinal differences in $b$ at Peru (this study; Martin et al., 1987) could simply reflect bias from comparing benthic- and pelagic-derived rain rates from a complex margin system displaying high temporal variability in productivity (Walsh et al., 1981).

\section{Conclusions}

Fieldwork undertaken on the fascinating Peruvian margin has improved our understanding of POC cycling in anoxic margin sediments and expanded the existing CBE database. Our key findings are as follows: (1) low CBE in shelf sediments is driven by the episodic intrusion of oxygenated waters. This is consistent with the existing CBE database if the shelf can be geochemically classified as a "normal" setting despite fluctuating bottom water $\mathrm{O}_{2}$ levels. Previous biochemical analyses suggest that this is the case. (2) High CBE in oxygenated waters $\left(\mathrm{O}_{2}>20 \mu \mathrm{M}\right)$ below the OMZ is caused by the deposition of reworked, degraded material originating from sites higher up on the slope. They are, therefore, not representative of oxygenated sediments. (3) Low oxygen concentrations in the OMZ below $200 \mathrm{~m}$ are associated with the preservation of POC in sediments, although the redistribution and accumulation of reworked sediments at these depths needs to be more clearly examined. (4) POC rain rates do not appear to be overly enhanced by low oxygen concentrations compared to other oxygen-deficient environments.

Our conclusions regarding this last point require further validation with particle flux measurements from sediment traps. Trap data may reveal lower rates of POC mineralisation in the water column, as observed in other low-oxygen settings. If this turns out to be the case, it would imply that POC fluxes are either subject to high temporal variability, or that a fraction of labile material resuspended from the sea bed is degraded in the benthic boundary layer and exported down the slope. The increase in sedimentation rates and high CBE below the OMZ supports the latter alternative. These investigations would benefit from an improved understanding of particle disaggregation by zooplankton and subsequent stimulation of the microbial loop (Giering et al., 2014).

A major outstanding barrier for deriving annual carbon and nutrient budgets on the Peruvian margin is the uncertainty associated with non-steady-state conditions. Inter- and intra-annual oceanographic anomalies dictate the depth and intensity of oxygen-deficiency, nutrient levels and Thioploca 
spp. biomass (Gutiérrez et al., 2008). Consequently, the contribution of the sediments to primary production on short (e.g. days, weeks) and long (e.g. months, years) timescales is completely unknown. This is a topic that could be tackled by incorporating benthic processes into the pelagic model ROMS-BioEBUS. Model predictions would be strengthened with benthic flux data collected during the low productivity season (austral winter). 


\section{Appendix A: Uncertainties in CBE calculations}

The burial efficiency of carbon is the basic quantitative metric that allows comparisons of carbon preservation at different locations. Quantification of the CBE requires at least two of the following three pieces of information: (i) the rain rate of organic carbon to the sediment; (ii) the rate of carbon burial at the sediment depth where POC content remains constant; and (iii) the depth-integrated rate of organic carbon oxidation (Burdige, 2007). That is, at steady-state, (i) $=$ (ii) + (iii). They are typically quantified using (in the same order) (i) sediment trap particle fluxes; (ii) sedimentation rates (using radioactive isotopes) combined with carbon content measurements; and (iii) stoichiometric mass balances, diagenetic models or benthic fluxes. Each of these approaches integrates the carbon flux over very different timescales; from days to weeks for traps to hundreds or thousands of years for burial (Burdige, 2007). This temporal decoupling creates uncertainty that may affect CBE estimates.

Our calculated CBE rely on the use of benthic data only (i.e. (ii) and (iii) above) as opposed to sediment trap fluxes. It is well known that sediment trap data have multiple sources of uncertainty (Buesseler et al., 2007). Traps only capture the settling flux on timescales of deployment, typically days to weeks, which may be insufficient to capture temporal variability (Haake et al., 1992). Traps may also underestimate the particle flux in water depths $<1500 \mathrm{~m}$ due to high lateral current velocities (Yu et al., 2001), potentially leading to an overestimate of fluxes further offshore. This effect is exacerbated over the shelf and upper slope where particles are transported in the benthic boundary layer (Jahnke et al., 1990). These dynamics may be particularly pertinent for the Peru margin where sediments are frequently resuspended by bottom currents and transported down the slope (Reimers and Suess, 1983c). Nonetheless, sedimentation rate and carbon oxidation rate calculations are not free from their own uncertainties, as discussed in the subsequent paragraphs.

Benthic chambers are arguably the best tools to estimate the exchange of solutes between the sediments and the water column (Tengberg et al., 2005). Yet, as for traps, DIC flux may display short-term (sub-annual) variability via changes in productivity and thus not truly reflect the long-term mean degradation rate. Mean PP estimates using the pelagic model do reveal substantial intra-annual variability on the Peru margin (Fig. S4). Both campaigns at 11 and $12^{\circ} \mathrm{S}$ took place toward the end of austral summer, that is, the high productivity season, which suggests a bias in our DIC fluxes towards higher values (Echevin et al., 2008). However, because benthic carbon mineralisation rates do not respond quantitatively and synchronously to changes in rain rate, it is not possible to accurately ascertain if the fieldwork timing adversely affects our assumption that the measured DIC flux accurately represents the mean flux. The timescale of the bulk organic carbon mineralisation is determined by the reactivity of the individual biomolecules, which vary over many orders of magnitude
(Middelburg, 1989). Experiments with fresh phytoplankton have shown that approximately $50 \%$ of organic carbon degrades rapidly within 1 month of deposition on the seafloor, with the other $50 \%$ requiring many months or years to degrade (Westrich and Berner, 1984). This implies that variability in the measured benthic DIC fluxes will largely reflect the previous month of deposition of the labile POC fraction. In that regard, the benthic DIC flux provides a more attenuated estimate of changes in rain rate than sediment trap data. Based on the modelled primary production rates during the sampling months, which were around $25 \%$ higher than the annual mean (Fig. S4), we tentatively estimate that the measured DIC fluxes at $12^{\circ} \mathrm{S}$ are roughly $25 \%$ higher than the long-term average. The analytical error on the DIC flux calculation from TA and $p \mathrm{CO}_{2}$ measurements is negligible by comparison. Correcting the DIC flux for seasonal variability would increase our CBE estimates by around 4 to $5 \%$ on the shelf and 5 to $7 \%$ in deeper waters. Strictly, though, the mean DIC flux for the last ca. 100 years would be required to be consistent with the burial data.

Artifacts in flux estimates due to enclosure of bottom water by benthic chambers have been discussed extensively in the literature (e.g. Hammond et al., 1996; Tengberg et al., 2005). Uncertainty in chamber volume, leakage and improper alteration of the hydrodynamic regime inside the chambers all influence our confidence in any particular concentration measurement or flux estimate. We can be reasonably confident that leakage through the bottom of the chambers in contact with the sediments did not occur at the sampling stations. Silicate (assumed conservative tracer) and $\mathrm{O}_{2}$ (optode) concentration gradients inside the chambers were linear and showed no evidence of infiltration of chamber water by the outside bottom water (Sommer et al., unpublished data). Furthermore, the surface sediments were cohesive and porous along the whole margin (Table 1), allowing penetration of the benthic chambers to 8 to $10 \mathrm{~cm}$ below the sediment surface and rendering leakage unlikely. Yet, we cannot rule out the possibility that the measured DIC fluxes deviated from the true fluxes due to changes in water flow across the sediment-water interface. This artifact is mostly prominent in sandy sediments where current-driven advection through the surface layers contributes significantly to solute exchange between sediments and seawater (Jahnke et al., 2000). The cohesive and fine-grained sediments (sandy mud to slightly sandy mud) at Peru typically have low permeability where molecular diffusion dictates the benthic flux. Thus, error in the DIC flux due to chamber artifacts as well as seasonal variability is likely to be much smaller than the difference in DIC flux measured in the two chambers during each lander deployment, that is, due to seafloor heterogeneity (Table 2).

POC accumulation rates have a relative error determined by the uncertainty in $\omega_{a c c}$ and POC content. The uncertainty in POC content was assumed to be $\pm 20 \%$, mainly due to data scatter. Whilst this is realistic for most of the sites investigated here, productivity and sediment POC content have 
increased on the Peruvian margin in the last 200 years, coinciding with the expansion of the OMZ driven by a northward displacement of the Intertropical Convergence Zone (Gutiérrez et al., 2009). This is clearly seen in the upper $10 \mathrm{~cm}$ of the outer shelf and OMZ sediments (Fig. 4) and undermines our ability to accurately define the depth where the POC content shows little change with sediment depth. The regime shift is not recorded at the middle shelf sites because the high sedimentation rates restrict the observable archive to the last 100 years. Similarly, the deep stations below the OMZ are presumably beyond the sphere of influence of short-term climactic variations. These sites show the expected decrease in POC for sediments undergoing steady-state mineralisation with very little mixing by bioturbation. For the stations affected by the regime shift (St. 4 to 7), we calculated the CBE based on the average POC content in this recent layer (upper $\sim 10 \mathrm{~cm}$ ) where our ${ }^{210} \mathrm{~Pb}_{\mathrm{xs}}$ measurements were made. A $50 \%$ decrease in POC content at these stations would lower the CBE by 20 to $40 \%$. Note that higher POC mineralisation rates associated with the increase in POC content over recent centennial time scales should be accurately reflected in the DIC flux. Diffusive path lengths calculations (Lasaga and Holland, 1976) show that DIC concentrations in the upper $10 \mathrm{~cm}$ will adjust to higher POC fluxes within a few years only.

Sediment accumulation rates $\left(\omega_{\text {acc }}\right)$ were constrained using ${ }^{210} \mathrm{~Pb}_{\mathrm{xs}}$ data (half-life of $22 \mathrm{yr}$ ) using a model that utilises a widely used empirical description of bioturbation intensity with sediment depth (Christensen, 1982). We estimated that $\omega_{\text {acc }}$ are accurate to within $\pm 20 \%$ for the derived bioturbation coefficients (Table S2). Continuously supplied tracers such as the ${ }^{210} \mathrm{~Pb}_{\mathrm{xs}}$ radioisotope have a characteristic timescale equal to about 5 half-lives, that is, ca. $110 \mathrm{yr}$. Therefore, our accumulation rates correspond to recent sediments deposited since the Little Ice Age and are of the same order as those published previously for the same area (Reimers and Suess, 1983c; Kim and Burnett, 1988; Levin et al., 2002; Gutiérrez et al., 2009). They are not applicable to the older underlying sediment, where mass accumulation rates are lower and have undergone hiatuses in the past (Reimers and Suess, 1983b; Gutiérrez et al., 2009; Schönfeld et al., 2014). However, sedimentation and bioturbation rates inferred from radioisotopes with vastly different half-lives often differ by an order-of-magnitude or more (e.g. Smith et al., 1993). Bioturbation coefficients of ca. $100 \mathrm{~cm}^{2} \mathrm{yr}^{-1}$ were derived from ${ }^{234} \mathrm{Th}$ (half-life $24 \mathrm{~d}$ ) distributions below the OMZ on the Peru margin (Levin et al., 2002), which is four orders-of-magnitude higher than we determined using ${ }^{210} \mathrm{~Pb}_{\mathrm{xs}}$. Given the low sedimentation and bioturbation rates at the deeper stations, the ${ }^{210} \mathrm{~Pb}_{\mathrm{xs}}$ distributions may thus indicate higher rates of sediment mixing and lower sedimentation rates than derived with the model.
We used the anthropogenic enrichment peak of the nuclide ${ }^{241} \mathrm{Am}$ as an independent time marker to validate the lead chronology (Fig. 2). ${ }^{241} \mathrm{Am}$ originates from nuclear tests in the Southern Hemisphere beginning in the early 1950s. At four stations, $\omega_{\text {acc }}$ was estimated by dividing the depth of the ${ }^{241} \mathrm{Am}$ peak by 60 years without correcting for compaction, resulting in rates of $0.15 \mathrm{~cm} \mathrm{yr}^{-1}$ at $S t .5$, and $0.05 \mathrm{~cm} \mathrm{yr}^{-1}$ at St. 4, 7, and 9. No ${ }^{241} \mathrm{Am}$ was detectable at the other stations. These rates agree with the ${ }^{210} \mathrm{~Pb}_{\mathrm{xs}}$ values to within 10 to $50 \%$ (Table 2). Although $\omega_{\text {acc }}$ estimated this way are only approximate, they confirm the order-of-magnitude values determined by the ${ }^{210} \mathrm{~Pb}_{\mathrm{xs}}$ model. Furthermore, it is obvious that the ${ }^{234} \mathrm{Th}$-derived bioturbation coefficient of $100 \mathrm{~cm}^{2} \mathrm{yr}^{-1}$ does not capture the activity of the ${ }^{210} \mathrm{~Pb}_{\mathrm{xs}}$ data (red curve, Fig. 2). The high ${ }^{234} \mathrm{Th}$-derived coefficient is very likely a model artifact caused by the use of short-lived radioisotopes to infer mixing rates in weakly mixed sediments (Lecroart et al., 2010).

Clearly, there are multiple potential sources of uncertainty in CBE estimates based on DIC fluxes and POC burial fluxes. Yet, whilst concerns remain regarding both short- and longterm variability in fluxes, we believe our derived CBEs are robust on decadal timescales. The mean relative error in $\mathrm{CBE}$ across all stations is around $40 \%$ (at $12^{\circ} \mathrm{S}$ ); a fair representation of the combined uncertainties. 


\section{The Supplement related to this article is available online at doi:10.5194/bg-12-1537-2015-supplement.}

Acknowledgements. We thank the captains and crew of RV Meteor cruises M77 and M92 for their assistance during the fieldwork. Biogeochemical analyses were performed with the invaluable assistance of B. Domeyer, M. Dibbern, R. Ebbinghaus, R. Suhrberg, S. Trinkler and V. Thoenissen. Preparation and deployment of large instruments was smoothly achieved with the wizardry of S. Kriwanek, A. Petersen, M. Türk and S. Cherednichenko. We would also like to thank R. Schulz from the Laboratory for Radioisotopes (LARI) at the University of Göttingen for the ${ }^{210} \mathrm{~Pb}$ analyses. Our colleague Rainer Kiko is also kindly acknowledged for insightful discussions on pelagic particle transport. The authors also thank Lisa Levin for handling the manuscript and two anonymous reviewers for their detailed commentaries. This work is a contribution of the Sonderforschungsbereich 754 "Climate - Biogeochemistry Interactions in the Tropical Ocean" (www.sfb754.de) which is supported by the Deutsche Forschungsgemeinschaft.

Edited by: L. Levin

\section{References}

Aller, R. C.: Bioturbation and remineralization of sedimentary organic matter: effects of redox oscillation, Chem. Geol., 114, 331345, 1994

Aller, R. C.: Mobile deltaic and continental shelf muds as suboxic, fluidized bed reactors, Mar. Chem., 61, 143-155, 1998.

Arntz, W. E., Tarazona, J., Gallardo, V. A., Flores, L. A., and Salzwedel, H.: Benthos communities in oxygen deficient shelf and upper slope areas of the Peruvian and Chilean Pacific coast, and changes caused by El Nińo, in: Modern and Ancient Continental Shelf Anoxia, Tyson, edited by: R. V. and Pearson, T. H., Geol. Soc. Spec. Pub., 58, 131-154, 1991.

Arthur, M. A., Dean, W. E., and Laarkamp, K.: Organic carbon accumulation and preservation in surface sediments on the Peru margin, Chem. Geol., 152, 273-286, 1998.

Berelson, W. M.: The flux of particulate organic carbon into the ocean interior: a comparison of four US JGOFS regional studies, Oceanography, 14, 59-67, 2001.

Berelson, W. M., McManus, J., Coale, K. H., Johnson, K. S., Kilgore, T., Burdige, D., and Pilskaln, C.: Biogenic matter diagenesis on the sea floor: A comparison between two continental margin transects, J. Mar. Res., 54, 731-762, 1996.

Bergamaschi, B. A., Tsamakis, E., Keil, R. G., Eglinton, T. I., Montlucon, D. B., and Hedges, J.: I. The effect of grain size and surface area on organic matter, lignin and carbohydrate concentration, and molecular compositions in Peru Margin sediments, Geochim. Cosmochim. Acta, 61, 1247-1260, 1997.

Berner, R. A.: The Phanerozoic Carbon Cycle: $\mathrm{CO}_{2}$ and $\mathrm{O}_{2}$, Oxford University Press, Oxford, 2004.

Betzer, P. R., Showers, W. J., Laws, E. A., Winn, C. D., DiTullio, G. R., and Kroopnick, P. R.: Primary productivity and particle fluxes on a transect of the equator at $153^{\circ} \mathrm{W}$ in the Pacific Ocean, Deep-Sea Res., 31, 1-11, 1984.
Bohlen, L., Dale, A. W., Sommer, S., Mosch, T., Hensen, C., Noffke, A., Scholz, F., and Wallmann, K.: Benthic nitrogen cycling traversing the Peruvian oxygen minimum zone, Geochim. Cosmochim. Ac., 75, 6094-6111, 2011.

Böning, P., Brumsack, H. J., Böttcher, M. E., Schnetger, B., Kriete, C., Kallmeyer, J., and Borchers, S. L., Geochemistry of Peruvian near-surface sediments, Geochim. Cosmochim. Acta, 68, 44294451, 2004.

Boudreau, B. P.: A method-of-lines code for carbon and nutrient diagenesis in aquatic sediments, Comp. Geosci., 22, 479-496, 1996.

Buesseler, K. O., Antia, A. N., Chen, M., Fowler, S. W., Gardner, W. D., Gustafsson, Ö., Harada, K., Michaels, A. F., Rutgers v. d. Loeff, M., Sarin, M., Steinberg, D. K., and Trull, T:. An assessment of the use of sediment traps for estimating upper ocean particle fluxes, J. Mar. Res., 65, 345-416, 2007.

Burdige, D. J.: Geochemistry of Marine Sediments, Princeton University Press, Princeton, 2006.

Burdige, D. J.: Preservation of organic matter in marine sediments: controls, mechanisms, and an imbalance in sediment organic carbon budgets? Chem. Rev., 107, 467-485, 2007.

Burwicz, E. B., Rüpke, L. H., and Wallmann, K.: Estimation of the global amount of submarine gas hydrates formed via microbial methane formation based on numerical reaction-transport modelling and a novel parameterization of Holocene sedimentation, Geochim. Cosmochim. Acta, 75, 4562-4576, 2011.

Cai, W. J. and Sayles, F. L: Oxygen penetration depths and fluxes in marine sediments, Mar. Chem., 52, 123-131, 1996.

Canfield, D. E.: Organic matter oxidation in marine sediments, in: Interactions of C, N, P and S Biogeochemical Cycles and Global Change, edited by: Wollast, R., Mackenzie, F. T., and Chou, L., NATO ASI Ser. I, 4, Springer, Berlin, 333-364, 1993.

Canfield, D. E.: Factors influencing organic carbon preservation in marine sediments, Chem. Geol., 114, 315-329, 1994.

CARS: CSIRO Atlas of Regional Seas, http://www.marine.csiro.au/ $\sim$ dunn/cars2009, last access: 12 August 2014.

Carton, J. A. and Giese, B. S.: A reanalysis of ocean climate using Simple Ocean Data Assimilation (SODA), Mon. Wea. Rev., 136, 2999-3017, 2008.

Chaigneau, A., Dominguez, N., Eldin, G., Vasquez, L., Flores, R., Grados, C., and Echevin, V.: Near-coastal circulation in the Northern Humboldt Current System from shipboard ADCP data, J. Geophys. Res-Oceans, 118, 5251-5266, 2013.

Christensen, E. R.: A model for radionuclides in sediments influenced by mixing and compaction, J. Geophys. Res. 87, 566-572, 1982.

Dale, A. W., Sommer, S., Ryabenko, E., Noffke, A., Bohlen, L., Wallmann, K., Stolpovsky, K. , Greinert, J., and Pfannkuche, O.: Benthic nitrogen fluxes and fractionation of nitrate in the Mauritanian oxygen minimum zone (Eastern Tropical North Atlantic), Geochim. Cosmochim. Acta, 134, 234-256, 2014.

Da Silva, A. M., Young, C. C., and Levitus, S.: Atlas of surface marine data 1994, vol. 1, Algorithms and procedures, technical report, Natl. Oceanogr. Atmos. Admin., Silver Spring, MD, 1994.

Demaison, G. J. and Moore, G. T.: Anoxic environments and oil source bed genesis, Am. Assoc. Petrol. Geolog. Bull., 64, 11791209, 1980. 
Devol, A. H. and Hartnett H. E.: Role of the oxygen-deficient zone in transfer of organic carbon to the deep ocean, Limnol. Oceanogr., 46, 1684-1690, 2001.

Dunne, J. P., Armstrong, R. A., Gnanadesikan, A., and Sarmiento, J. L.: Empirical and mechanistic models for the particle export ratio, Glob. Biogeochem. Cy., 19, GB4026, doi:10.1029/2004GB002390, 2005.

Echevin, V., Aumont, O., Ledesms, J., and Flores, G.: The seasonal cycle of surface chlorophyll in the Peruvian upwelling system: A modelling study, Prog. Oceanogr., 79, 167-176, 2008.

Fiedler P. C. and Talley L. D.: Hydrography of the eastern tropical Pacific: A review. Prog. Oceanogr., 69, 143-180, 2006.

Flemming, B. H.: A revised textural classification of gravel-free muddy sediments on the basis of ternary diagrams, Cont. Shelf Res., 20, 1125-1137, 2000.

Fuenzalida R., Schneider W., Garcés-Vargas J., Bravo L., and Lange C.: Vertical and horizontal extension of the oxygen minimum zone in the eastern South Pacific Ocean, Deep Sea Res. II, 56, 1027-1038, 2009.

Gallardo, V. A.: Large benthic microbial communities in sulphide biota under Peru-Chile subsurface countercurrent, Nature, 268, 331-332, 1977.

Giering, S. L. C., Sanders, R., Lampitt, R. S., Anderson, T. R., Tamburini, C., Boutrif, M., Zubkov, M. V., Marsay, C. M., Henson, S. A., Saw, K., Cook, K., and Mayor, D. J.: Reconciliation of the carbon budget in the ocean's twilight zone, Nature, 507, 480483, 2014.

Glenn, C. R. and Arthur, M. A.: Petrology and major element geochemistry of Peru margin phosphorites and associated diagenetic minerals: Authigenesis in modern organic-rich sediments., Mar. Geol., 80, 231-267, 1988.

Glock, N., Schönfeld, J., Eisenhauer, A., Hensen, C., Mallon, J., and Sommer, S.: The role of benthic foraminifera in the benthic nitrogen cycle of the Peruvian oxygen minimum zone, Biogeosciences, 10, 4767-4783, doi:10.5194/bg-10-4767-2013, 2013.

Grasshoff K., Ehrhardt M. and Kremling K.: Methods of Seawater Analysis. Wiley-VCH, Weinheim, 1999.

Gutiérrez, D., Gallardo, V. A., Mayor, S., Neira, C., Vásquez, C., Sellanes, J., Rivas, M., Soto, A., Carrasco, F., and Baltaza, M.: Effects of dissolved oxygen and fresh organic matter on the bioturbation potential of macrofauna in sublittoral sediments off Central Chile during the 1997/1998 El Niño, Mar. Ecol. Prog. Ser., 202, 81-99, 2000.

Gutiérrez, D., Enríquez, E., Purca, S., Quipúzcoa, L., Marquina, R., Flores, G., and Graco, M.: Oxygenation episodes on the continental shelf of central Peru: Remote forcing and benthic ecosystem response, Prog. Oceanogr., 79, 177-189, 2008.

Gutiérrez, D., Sifeddine, A., Field, D. B., Ortlieb, L., Vargas, G., Chávez, F. P., Velazco, F., Ferreira, V., Tapia, P., Salvatteci, R., Boucher, H., Morales, M. C., Valdés, J., Reyss, J.-L., Campusano, A., Boussafir, M., Mandeng-Yogo, M., García, M., and Baumgartner, T.: Rapid reorganization in ocean biogeochemistry off Peru towards the end of the Little Ice Age, Biogeosciences, 6, 835-848, doi:10.5194/bg-6-835-2009, 2009.

Gutknecht, E., Dadou, I., Marchesiello, P., Cambon, G., Le Vu, B., Sudre, J., Garçon, V., Machu, E., Rixen, T., Kock, A., Flohr, A., Paulmier, A., and Lavik, G.: Nitrogen transfers off Walvis Bay: a 3-D coupled physical/biogeochemical modeling approach in the Namibian upwelling system, Biogeosciences, 10, 4117 4135, doi:10.5194/bg-10-4117-2013, 2013.

Haake, B., V Ittekkot, V., Ramaswamy, V., Nairb, R. R., and Honjo, S.: Fluxes of amino acids and hexosamines to the deep Arabian Sea, Mar. Chem., 40, 291-314, 1992.

Haffert, L., Haeckel, M., Liebetrau, V., Berndt, C., Hensen, C., Nuzzo, M., Reitz, A., Scholz, F., Schönfeld, J., Perez-Garcia, C., and Weise, S. M.: Fluid evolution and authigenic mineral paragenesis related to salt diapirism - The Mercator mud volcano in the Gulf of Cadiz, Geochim. Cosmochim. Acta, 106, 261-286, 2013.

Hammond, D. E., McManus, J., Berelson, W. M., Kilgore, T. E., and Pope, R. H.: Early diagenesis of organic material in equatorial Pacific sediments: stoichiometry and kinetics, Deep-Sea Res. Pt. II, 43, 1365-1412, 1996.

Hartnett H. E., Keil R. G., Hedges J. I., and Devol A. H.: Influence of oxygen exposure time on organic carbon preservation in continental margin sediments, Nature, 391, 572-574, 1998.

Hedges, J. I. and Keil R. G.: Sedimentary organic matter preservation: an assessment and speculative synthesis, Mar. Chem., 49, 81-115, 1995.

Hedges, J. I., Hu, F. S., Devol, A. H., Hartnett H. E., Tsamakis, E., and Keil, R. G.: Sedimentary organic matter preservation: A test for selective degradation under oxic conditions, Am. J. Sci., 299, 529-555, 1999.

Henrichs, S. M. and Farrington, J. W.: Peru upwelling region sediments near $15^{\circ} \mathrm{S} .1$. Remineralization and accumulation of organic matter, Limnol. Oceanogr., 29, 1-19, 1984.

Hosegood P. and van Haren H.: Near-bed solibores over the continental slope in the Faeroe-Shetland Channel. Deep-Sea Res. II, 51, 2943-71, 2004.

Huettel, M., Forster, S., Kloser, S., and Fossing, H.: Vertical migration in the sediment-dwelling sulfur bacteria Thioploca spp. in overcoming diffusion limitations, App. Environm. Microbiol., 62, 1863-1872, 1996.

Hulthe, G., Hulth, S., and Hall, P. O. J.: Effect of oxygen on degradation rate of refractory and labile organic matter in continental margin sediments, Geochim. Cosmochim. Acta, 62, 1319-1328, 1998.

Jahnke, R. A., Reimers, C. E., and Craven, D. B.: Intensification of recycling of organic matter at the sea floor near ocean margins, Nature, 348, 50-54, 1990.

Jahnke, R. A., Nelson, J. R., Marinelli, R. L., and Eckman, J. E.: Benthic flux of biogenic elements on the Southeastern US continental shelf: influence of pore water advective transport and benthic microalgae, Cont. Shelf Res., 20, 109-127, 2000.

Jørgensen, B. B. and Gallardo, V. A.: Thioploca spp: filamentous sulfur bacteria with nitrate vacuoles, FEMS Microbiol. Ecol., 28, 301-313, 1999.

Kalvelage, T., Lavik, G., Lam, P., Contreras, S., Arteaga, L., Löscher, C. R., Oschlies, A., Paulmier, A., Stramma, L., and Kuypers, M. M. M.: Nitrogen cycling driven by organic matter export in the South Pacific oxygen minimum zone, Nat. Geosci., 6, 228-234, 2013.

Keil, R. G. and Cowie, G. L.: Organic matter preservation through the oxygen-deficient zone of the NE Arabian Sea as discerned by organic carbon: mineral surface area ratios, Mar. Geol., 161, 13-22, 1999 
Keil, R. G., Montlucon, D. B., Prahl, F. G., and Hedges, J. I.: Sorptive preservation of labile organic matter in marine sediments, Nature, 370, 549-552, 1994.

Kim, K. H. and Burnett, W. C.: Accumulation and biological mixing of Peru margin sediments, Mar. Geol., 80, 181-194, 1988.

Koho, K. A., Nierop, K. G. J., Moodley, L., Middelburg, J. J., Pozzato, L., Soetaert, K., van der Plicht, J., and Reichart, G.J.: Microbial bioavailability regulates organic matter preservation in marine sediments, Biogeosciences, 10, 1131-1141, doi:10.5194/bg-10-1131-2013, 2013.

Koné, V., Machu, E., Penven, P., Andersen, V., Garçon,V., Fréon, P., and Demarcq, H.: Modelling the primary and secondary productions of the southern Benguela upwelling system: A comparative study through two biogeochemical models, Glob. Biogeochem. Cy., 19, GB4021, doi:10.1029/2004GB002427, 2005.

Krissek, L. A., Scheideddger, K. F., and Kulm, L. V.: Surface sediments of the Peru-Chile continental margin and the Nazca plate, Geol. Soc. Am. Bull., 91, 321-331, 1980.

Lasaga, A. C. and Holland, H. D.: Mathematical aspects of nonsteady-state diagenesis, Geochim. Cosmochim. Acta, 40, 257266, 1976.

Lecroart, P., Maire, O., Schmidt, S., Grémare, A., Anschutz, P., and Meysman, F. J. R.: Bioturbation, short-lived radioisotopes, and the tracer-dependence of biodiffusion coefficients, Geochim. Cosmochim. Acta, 74, 6049-6063, 2010.

Levin, L., Gutiérrez, D., Rathburn, A., Neira, C., Sellanes, J., Muñoz, P., Gallardo, V., and Salamanca, M.: Benthic processes on the Peru margin: a transect across the oxygen minimum zone during the 1997-98 El Niño, Prog. Oceanogr., 53, 1-27, 2002.

Lomstein, B. A., Niggemann, J., Jørgensen, B. B., and Langerhuus, A. T.: Accumulation of prokaryotic remains during organic matter diagenesis in surface sediments off Peru, Limnol. Oceanogr., 54, 1139-1151, 2009.

Liu, W.T., Tang, W., and Polito, P. S.: NASA scatterometer provides global ocean-surface wind fields with more structures than numerical weather prediction, Geophys. Res. Lett., 25, 761-764, 1998.

Martin, J. H., Knauer, G. A., Karl, D. M., and Broenkow, W. W.: VERTEX: Carbon cycling in the northeast Pacific, Deep Sea Res. A. Oceanogr. Res. Pap., 34, 267-285, 1987.

Martini, K. I., Alford, M. H., Kunze, E., Kelly, S. M., and Nash, J. D.: Internal bores and breaking internal tides on the Oregon continental slope. J. Phys. Oceanogr., 43, 120-139, 2013.

Mayer, L. M.: Surface area control of organic carbon accumulation in continental shelf sediments, Geochim. Cosmochim. Acta, 58, 1271-1284, 1994.

Middelburg, J. J.: A simple rate model for organic matter decomposition in marine sediments, Geochim. Cosmochim. Acta, 53, 1577-1581, 1989.

Montes, I., Dewitte, B., Gutknecht, E., Paulmier, A., Dadou, I., Oschlies, A., and Garçon, V.: High-resolution modelling of the Eastern Tropical Pacific Oxygen Minimum Zone: Sensitivity to the tropical oceanic circulation, J. Geophys. Res., 119, 55155532, doi:10.1002/2014JC009858, 2014

Morales, C. E., Hormazabal, S. E., and Blanco, J. L.: Interannual variability in the mesoscale distribution of the depth of the upper boundary of the oxygen minimum layer off northern Chile (18$24^{\circ} \mathrm{S}$ ): Implications for the pelagic system and biogeochemical cycling, J. Mar. Res., 57, 909-932, 1999.
Morel, A. and Berthon, J. A.: Surface pigments, algal biomass profiles, and potential production of the euphotic layer: Relationships reinvestigated in view of remote-sensing applications, Limnol. Oceanogr., 34, 1545-1562, 1989.

Mosch, T., Sommer, S., Dengler, M., Noffke, A., Bohlen, L., Pfannkuche, O., Liebetrau, V., and Wallmann, K.: Factors influencing the distribution of epibenthic megafauna across the Peruvian oxygen minimum zone, Deep Sea Res. I., 68, 123-135, 2012.

Müller, P. J. and Suess, E.: Productivity, sedimentation rate, and sedimentary organic matter in the oceans - I. Organic carbon preservation. Deep Sea Res. A. Oceanogr. Res. Pap., 26, 1347-1362, 1979.

Niggemann, J. and Schubert, C. J.: Sources and fate of amino sugars in coastal Peruvian sediments. Geochim. Cosmochim. Acta, 70, 2229-2237, 2006.

Noffke, A., Hensen, C., Sommer, S., Scholz, F., Bohlen, L., Mosch, T., Graco, M., and Wallmann, K.: Benthic iron and phosphorus fluxes across the Peruvian oxygen minimum zone, Limnol. Oceanogr., 57, 851-867, 2012.

O’Reilly, J. E., Maritorena, S., Siegel, D. A., O’Brien, M. C., Toole, D., Chavez, F. P., Strutton, P., Cota, G. F., Hooker, S. B., McClain, C. R., Carder, K. L., Muller-Karger, F., Harding, L., Magnuson, A., Phinney, D., Moore, G. F., Aiken, J., Arrigo, K. R., Letelier, R., and Culver, M.: Ocean chlorophyll a algorithms for SeaWiFS, $\mathrm{OC}_{2}$, and $\mathrm{OC}_{4}$ : Version 4, in: O'Reilly, J. E., and 24 coauthors, SeaWiFS Post launch Calibration and Validation Analyses, Part 3, NASA Technical Memorandum 2000-206892, 11, 9-19, 2000.

Pedersen, T. F. and Calvert, S. E.: Anoxia vs productivity: what controls the formation of organic carbon-rich sediments and sedimentary rocks? Am. Assoc. Petrol. Geol. Bull., 74, 454-466, 1990.

Pennington, J. T., Mahoney, K. L., Kuwahara, V. S., Kolber D. D., Calienes R., and Chavez F. P.: Primary production in the eastern tropical Pacific: A review, Prog. Oceanogr., 69, 285-317, 2006.

Primeau, F.: On the variability of the exponent in the power law depth dependence of POC flux estimated from sediment traps, Deep-Sea Res. I 53, 1335-1343, 2006.

Quiñones, R. A., Gutierrez, M. H., Daneri, G., Aguilar, D. G., Gonzalez, H. E., Chavez, F. P.: The Humboldt Current System, in: Carbon and Nutrient Fluxes in Continental Margins: A Global Synthesis, edited by: Liu, K-. K., Atkinson, L., Quiñones, R., and Talaue-McManus, L., Springer-Verlag, Berlin, 44-64, 2010.

Redfield, A. C., Ketchum, B. H., and Richards, F. A.: The influence of organisms on the composition of seawater, in: The Sea, edited by: Hill, M. N., Interscience, New York, 26-77, 1963

Reimers, C. E. and Suess, E.: The partitioning of organic carbon fluxes and sedimentary organic matter decomposition rates in the ocean, Mar. Chem., 13, 141-168, 1983a.

Reimers, C. E. and Suess, E.: Late Quaternary fluctuations in the cycling of organic matter off central Peru: A proto-kerogen record, in: Coastal Upwelling, edited by: Suess, E. and Thiede, J., Its Sediment Record. Part A., Plenum Press, New York, 497-526, $1983 b$.

Reimers, C. E. and Suess, E. Spatial and temporal patterns of organic matter accumulation on the Peru continental margin, in: Coastal Upwelling, edited by: Suess, E. and Thiede, J., Its Sediment Record. Part B., Plenum Press, New York, 311-345, 1983c. 
Reimers, C. E., Jahnke, R. A., and McCorkle, D. C.: Carbon fluxes and burial rates over the continental slope and rise off central California with implications for the global carbon cycle. Glob. Biogeochem. Cy., 6, 199-224, 1992.

Ryan, J. P., Ueki, I., Chao, Y., Zhang, H., Polito, P. S., and Chavez, F. P.: Western Pacific modulation of large phytoplankton blooms in the central and eastern equatorial Pacific, J. Geophys. Res., 111, G02013, doi:10.1029/2005JG000084, 2006.

Sarmiento, J. L. and Gruber, N.: Ocean Biogeochemical Dynamics, Princeton University Press, Princeton, 2006.

Scholz, F., Hensen, C., Noffke, A., Rohde, A., Liebetrau, V., and Wallmann, K.: Early diagenesis of redox-sensitive trace metals in the Peru upwelling area - response to ENSO-related oxygen fluctuations in the water column, Geochim. Cosmochim. Acta, 75, 7257-7276, 2011.

Schönfeld, J., Kuhnt, W., Erdem, Z., Flögel, S., Glock, N., Aquit, M., Frank, M., and Holbourn, A.: Records of past mid-depth ventilation: Cretaceous ocean anoxic event 2 vs. Recent oxygen minimum zones, Biogeosciences, 12, 1169-1189, doi:10.5194/bg12-1169-2015, 2015.

Seiter, K., Hensen, C., Schröter, J., and Zabel, M.: Organic carbon content in surface sediments - defining regional provinces, Deep Sea Res. Pt. I, 51, 2001-2026, 2004.

Sellanes, J., Quiroga, E., Neira, C., and Gutiérrez, D.: 2007. Changes of macrobenthos composition under different ENSO cycle conditions on the continental shelf off central Chile, Cont. Shelf Res., 27, 1002-1016, 2007.

Shchepetkin, A. F. and J. C. McWilliams.: A method for computing horizontal pressure-gradient force in an oceanic model with a nonaligned vertical coordinate, J. Geophys. Res., 108, 3090, doi:10.1029/2001JC001047, 2003.

Smith, C. R., Pope, R. H., DeMaster, D. J., and Magaard, L.: Agedependent mixing of deep-sea sediments. Geochim. Cosmochim. Acta, 57, 1473-1488, 1993.

Sommer, S., Türk, M., Kriwanek, S., and Pfannkuche, O.: Gas exchange system for extended in situ benthic chamber flux measurements under controlled oxygen conditions: First application - Sea bed methane emission measurements at Captain Arutyunov mud volcano, Limnol. Oceanogr. Meth., 6, 23-33, 2008.

Sommer, S., Dengler, M., and Treude, T.: Benthic element cycling, fluxes and transport of solutes across the benthic boundary layer in the Peruvian oxygen minimum zone, (SFB 754) - Cruise No. M92 - 5 January-3 February 2013 - Callao (Peru) - Callao (Peru), METEOR-Berichte M92, 55 pp., DFGSenatskommission für Ozeanographie, doi:10.2312/cr_m92, 2014.

Suess, E.: Particulate organic carbon flux in the oceans - surface productivity and oxygen utilization, Nature, 288, 260-263, 1980.

Suess, E.: Phosphate regeneration from sediments of the Peru continental margin by dissolution of fish debris, Geochim. Cosmochim. Acta, 45, 577-588, 1981.
Suess, E., Kulm, L. D., and Killingley, J. S.: Coastal upwelling and a history of organic-rich mudstone deposition off Peru, in: Marine Petroleum Source Rocks, edited by: Brooks, J. and Fleet, A. J., Geol. Soc. Spec. Pub. 26, 181-197, 1987.

Suntharalingam, P., Sarmiento, J. L., and Toggweiler, J. R., Global significance of nitrous-oxide production and transport from oceanic low-oxygen zones: A modelling study, Glob. Biogeochem. Cy., 14, 1353-1370, 2000.

Suntharalingam, P., Buitenhuis, E., Le Quere, C., Dentener, F., Nevinson, C., Butler, L., Bange, H., and Forster, G.: Quantifying the impact of anthropogenic nitrogen deposition on oceanic nitrous oxide, Geophys. Res. Lett., 39, L07605, doi:10.1029/2011GL050778, 2012.

Tarazona, J., Salzwedel, H., and Arntz, W.: Positive effects of "El Nińo" on macrozoobenthos inhabiting hypoxic areas of the Peruvian upwelling system, Oecologia, 76, 184-190, 1988.

Tengberg, A., Halle P. O. J., Andersson, P., Lindén, B., Styrenius, O., Boland, G., de Bovee, F., Carlsson, B., Ceradini, S., Devol, A., Duineveld, G., Friemann, J. U., Glud, R. N., Khripounoff, A., Leather, J., Linke, P., Lund-Hansen, L., Rowe, G., Santschi, P., de Wilde, P., and Witte, U.: Intercalibration of benthic flux chambers II. Hydrodynamic characterization and flux comparisons of 14 different designs, Mar. Chem., 94, 147-173, 2005.

Van Mooy, B. A. S., Keil, R. G., and Devol, A. H.: Impact of suboxia on sinking particulate organic carbon: Enhanced carbon flux and preferential degradation of amino acids via denitrification, Geochim. Cosmochim. Acta, 66, 457-465, 2002.

Vandewiele, S., Cowie, G., Soetaert, K., and Middelburg, J. J.: Amino acid biogeochemistry and organic matter degradation state across the Pakistan margin oxygen minimum zone, Deep Sea Res. Pt. II, 56, 318-334, 2009.

Wallmann, K. and Aloisi, G.: The Global Carbon Cycle: Geological Processes, in: Fundamentals of Geobiology, edietd by: Knoll, A. H., Canfield, D. E., and Konhauser., K. O., Blackwell Publishing Ltd., 20-35, 2012.

Walsh, J. J.: A carbon budget for overfishing off Peru, Nature, 290, 300-304, 1981.

Westrich, J. T. and Berner, R. A.: The role of sedimentary organic matter in bacterial sulfate reduction: the G-model tested, Limnol. Oceanogr., 29, 236-249, 1984.

Yu, E. F., Francois, R., Bacon, M. P., Honjo, S., Fleer, A. P., Manganini, S. J., Rutgers van der Loeff, M. M., and Ittekot, V.: Trapping efficiency of bottom-tethered sediment traps estimated from the intercepted fluxes of ${ }^{230} \mathrm{Th}$ and ${ }^{231} \mathrm{~Pa}$, Deep-Sea Res. Pt. I, 48, 865-889, 2001.

Zeebe, R. E. and Wolf-Gladrow, D. A.: $\mathrm{CO}_{2}$ in Seawater: Equilibrium, Kinetics, Isotopes, Elsevier Oceanography Series, Amsterdam, 2001.

Zonneveld, K. A. F., Versteegh, G. J. M., Kasten, S., Eglinton, T. I., Emeis, K.-C., Huguet, C., Koch, B. P., de Lange, G. J., de Leeuw, J. W., Middelburg, J. J., Mollenhauer, G., Prahl, F. G., Rethemeyer, J., and Wakeham, S. G.: Selective preservation of organic matter in marine environments; processes and impact on the sedimentary record, Biogeosciences, 7, 483-511, doi:10.5194/bg-7483-2010, 2010. 